\section{A systematic review of the physical and chemical characteristics of pollutants from biomass burning and combustion of fossil fuels and health effects in Brazil}

\author{
Revisão sistemática das características físico- \\ químicas dos poluentes atmosféricos provenientes \\ das queimadas e combustíveis fósseis e efeitos \\ na saúde no Brasil
}

Beatriz Fátima Alves de Oliveira 1

Eliane Ignotti 2

Sandra S. Hacon 1

\section{Introduction}

The aim of this study was to carry out a review of scientific literature published in Brazil between 2000 and 2009 on the characteristics of air pollutants from different emission sources, especially particulate matter (PM) and its effects on respiratory health. Using electronic databases, $a$ systematic literature review was performed of all research related to air pollutant emissions. Publications were analyzed to identify the physical and chemical characteristics of pollutants from different emission sources and their related effects on the respiratory system. The $P M_{2.5}$ is composed predominantly of organic compounds with $20 \%$ of inorganic elements. Higher concentrations of metals were detected in metropolitan areas than in biomass burning regions. The relative risk of hospital admissions due to respiratory diseases in children was higher than in the elderly population. The results of studies of health effects of air pollution are specific to the region where the emissions occurred and should not be used to depict the situation in other areas with different emission sources.

Environmental Pollutants; Air Pollutants; Particulate Matter; Respiratory Tract Diseases
Exposure to air pollutants has been shown by several epidemiological and toxicological studies to have noxious effects on human health $1,2,3$. Environmental exposure to particulate matter (PM) has been widely studied because of its physical characteristics and multi-elemental composition which varies depending on the emission source 4,5 .

The main sources of PM emissions are fossil fuel combustion and biomass burning 6,7. Globally, Brazil makes a significant contribution to PM emissions because some regions of the country have extremely high levels of air pollution. In the South and Southeast Regions, the development of automobiles and industry are the main cause of these high levels ${ }^{8}$, whereas in the southern and eastern Brazilian Amazon the expansion of agribusiness and forest fires are the main contributors to PM emissions, especially in the region known as the "Arc of Deforestation" 9.

Aerosol particles in the atmosphere influence the Earth's radiation balance and climate, atmospheric chemistry, visibility and human health on a local to global scale. The transport and deposition chemistry of these particles and their effects on solar radiation and human health depend largely on their size, distribution, composition, morphology and surface area 10 . These characteristics are important, especially in the Brazilian Amazon region where forest burning is 
widespread during the dry season. Studies show that individuals living in exposed areas located far from the source can demonstrate the same adverse respiratory effects as those experienced by individuals at the source itself 11 .

At the height of the dry season, between July and October, the Brazilian Amazon Region is responsible for approximately $70 \%$ of biomass burning in Brazil (Instituto Brasileiro do Meio Ambiente. http://www.ibama.gov.br/prevfogo/ areas-tematicas/monitoramento/dados-de-fo cos-de-calor, accessed on 10/Mar/2010) leading to significant damage to the savanna and Amazon Forest. On average, forest fires in the Brazilian Amazon are responsible for $67 \%$ of $\mathrm{PM}_{2.5}$ emissions 12,13. In other regions of Brazil, most fires are a result of sugarcane plantation burning 14. However, in metropolitan areas of Brazil the primary cause of PM emissions are motor vehicles 15 .

The health effects of atmospheric particles are influenced by particle size (aerodynamic diameter). The diameter of atmospheric particles ranges from $1 \mathrm{~nm}$ to $100 \mu \mathrm{m}$. $\mathrm{PM}_{10}$ and $\mathrm{PM}_{2.5}$ particles have an aerodynamic diameter of less than $10 \mu \mathrm{m}$ and $2.5 \mu \mathrm{m}$, respectively. Ultrafine particles, or $\mathrm{PM}_{0.1}$ particles, have a thermodynamic diameter of less than $0.1 \mu \mathrm{m}$. $\mathrm{PM}_{2.5}$ particle fractions are called "fine particles" and those particles with a diameter of between $10 \mu \mathrm{m}$ and $2.5 \mu \mathrm{m}$ are called “coarse particles" 3,4 .

The concentration, size, chemical composition and toxicological characteristics of pollutants, including PM, are determined by the emission source 4,16 . This study aims to present an overview of the scientific literature on the characteristics of air pollutants, especially particulate matter and their respiratory health effects, from the different types of sources of pollutant emissions in Brazil published between 2000 and 2009.

\section{Materials and methods}

\section{Study design}

A systematic literature review of all research related to vehicular, industrial and biomass burning pollutant emissions published between 2000 and 2009 was performed using electronic databases. Reviews of earlier studies were also conducted 14,17,18,19,20. Priority was given to publications on the physical and chemical characteristics of particulate matter from the different types of emission sources followed by studies related to respiratory system effects. The following criteria were used to select and analyze studies regarding the effects of PM on the respiratory system: study area, year of publication, source characteristics, susceptible group and health outcomes. Reviews and studies that did not show the outcome of respiratory diseases were excluded. Articles on the physical and chemical characteristics of PM were then reviewed using the following criteria: source characteristics, study area, year in which the data was collected, particle concentration and chemical composition. Only those studies that included information on particle size, concentration and elemental composition of aerosols were included.

To compare the respiratory effects of exposure to PM and the relative risk (RR) of mortality and hospitalization in children and the elderly, increments of $10 \mu \mathrm{g} / \mathrm{m}^{3}$ in $\mathrm{PM}_{10}$ levels were used. RR was recalculated for those articles that did not show a variation in concentrations of $10 \mu \mathrm{g} / \mathrm{m}^{3}$, and the standard error and coefficient $(\beta)$ were calculated for mortality and hospitalization related to variations in $\mathrm{PM}_{10}$ concentrations. Gouveia \& Fletcher 21,22 and Braga et al. 23 calculated the standard error and $\beta$ using RR and confidence interval (CI). This review only included the results of articles where RR and CI figures were described in tables or the text.

\section{Search strategy}

The search was conducted in Spanish, English and Portuguese in the following bibliographic databases: (i) Scientific Electronic Library Online (SciELO); (ii) Medical Literature Analysis and Retrieval System Online (MEDLINE); (iii) Latin American and Caribbean Health Science Literature (LILACS); (iv) U.S. National Library of Medicine (PubMed); (v) Scopus. Several descriptors and keywords in the title or abstract of the study were combined. The following terms were used: "air pollution"; "particulate matter"; "aerosol*”; "aerosol composition”; "biomass burning”; "sugarcane”, "emission sources”; "health effects"; "mortality"; “asthma”; "respiratory disease"; "pneumonia*”; “Amazon*”; "Brazil”.

Reports, texts, inventories and guides produced by the Large Scale Biosphere-Atmosphere Experiment in Amazonia (LBA; http://lba.inpa. gov.br/lba/), the World Health Organization (WHO; http://www.who.int/topics/air_pollu tion/en/), the Environment Protection Agency (EPA; http://www.epa.gov/air/airpollutants.ht $\mathrm{ml}$ ) and the National Institute for Space Research (INPE; http://sigma.cptec.inpe.br/queimadas/) were used as information sources for the discussion of the literature. Articles published in 2010 and which were not indexed during the search period were included in the discussion of results. 


\section{Results}

\section{Published articles}

Between 2000 and 2009, a total of 137 articles were published on the characteristics of PM from distinct emission sources and their effects on human health in Brazil. Ninety articles (66\%) deal with the adverse respiratory effects of air pollution of which 54 (60\%) were selected 21,22,23,24, $25,26,27,28,29,30,31,32,33,34,35,36,37,38,39,40,41,42,43,44,45,46$, $47,48,49,50,51,52,53,54,55,56,57,58,59,60,61,62,63,64,65,66,67$, $68,69,70,71,72,73,74$. The remaining 47 articles (34\%) were on the physical and chemical characteristics of pollutants, of which 39 (83\%) met the inclusion criteria for this review $7,8,12,13,52,58,65,75,76$, $77,78,79,80,81,82,83,84,85,86,87,88,89,90,91,92,93,94,95,96,97,98$, $99,100,101,102,103,104,105,106$

Approximately 20 publications dealt with the physical and chemical characteristics of vehicular, industrial and biomass burning pollutant emissions. The number of studies conducted in biomass burning areas was greater than the number conducted in metropolitan areas for all years apart from 2004, 2008 and 2009. The largest numbers of articles on fires were published in 2005, with 5 publications, whereas the largest numbers of articles on industrial sources and motor vehicles were published in 2008.

Most of the articles reviewed on health effects arising from exposure to particles derived from industry and motor vehicles in metropolitan areas were published in 2009. With respect to biomass burning, a total of 13 articles were published between 2000 and 2009 .

\section{Physical and chemical characteristics of pollutants derived from biomass burning}

A summary of the articles concerning the main physical and chemical characteristics of pollutants derived from biomass burning is presented in Table 1. The Amazon biome was the most studied area in articles on the physical and chemical characteristics of PM 77,82. Studies in this region show that $\mathrm{PM}_{10}$ and $\mathrm{PM}_{2.5}$ were predominantly composed of organic compounds $75,78,81,86$, and in the case of $\mathrm{PM}_{2.5}$ these substances made up $70 \%$ to $92 \%$ of its composition 75 . Among the organic elements, Black Carbon (BC) made up between $5 \%$ and $15 \%$ of $\mathrm{PM}_{2.5}$, with values ranging from $5.5 \mu \mathrm{g} / \mathrm{m}^{3}$ to $16 \mu \mathrm{g} / \mathrm{m}^{3}$ during peak burning 76,77. During the dry season in the Southeast Region of Brazil, BC levels from burning sugarcane were lower than those measured in the Brazilian Amazon 52,84.

In the Amazon biome, high concentrations of biogenic elements were identified for $\mathrm{PM}_{10}$ dur- ing the rainy season ${ }^{87}$. During the dry season, $\mathrm{PM}_{2.5}$ is predominantly composed of $\mathrm{BC}$, sulphates $\left(\mathrm{SO}_{4}{ }^{2-}\right)$, nitrates $\left(\mathrm{NO}_{3}\right)$ and metals $12,77,87$. Yamasoe et al. 75 investigated the chemical composition of $\mathrm{PM}_{2.5}$ relating to the burning phases or stages and detected that potassium $(\mathrm{K})$, chlorine $(\mathrm{Cl})$ and sulphate $\left(\mathrm{SO}_{4}{ }^{2-}\right)$ were the dominant chemical elements. Ammonia $\left(\mathrm{NH}_{3}\right)$ was also found in fractions of $\mathrm{PM}_{2.5}$ during the dry season in the Brazilian Amazon 77,81. These same characteristics were observed in the Southeast Region of Brazil in areas of sugarcane burning 52,80,84.

In biomass burning areas in the Southeast Region of Brazil and Brazilian Amazon region, studies identified concentrations of metals such as zinc $(\mathrm{Zn})$, iron $(\mathrm{Fe})$, lead $(\mathrm{Pb})$, copper $(\mathrm{Cu})$ and mercury (Hg) in the elemental composition of $\mathrm{PM}_{2.5}$. It is probable that mining activities are responsible for the concentrations of $\mathrm{Hg} \mathrm{12,75,76.}$

In the Brazilian Amazon, concentrations of $\mathrm{PM}_{10}$ and $\mathrm{PM}_{2.5}$ were higher during the dry season, reaching peaks of $600 \mu \mathrm{g} / \mathrm{m}^{3}$ and $350 \mu \mathrm{g} / \mathrm{m}^{3}$ respectively 77 , It should be noted however that this information comes from an article that referred to data collected in the 1990s. Sugarcane burning areas showed average $\mathrm{PM}_{2.5}$ levels ranging from $9.3 \mu \mathrm{g} / \mathrm{m}^{3}$ to $238 \mu \mathrm{g} / \mathrm{m}^{3}\left(\sigma 14.5 \mu \mathrm{g} / \mathrm{m}^{3}\right) 84$. Currently, the Amazon biome shows peak $\mathrm{PM}_{2.5}$ concentrations of between $225 \mu \mathrm{g} / \mathrm{m}^{3}$ (between September and November 2002) 85 and 450 $\mathrm{g} /$ $\mathrm{m}^{3}$ (September 2005) 65, whereas the Southeast Region, in areas of sugarcane burning, mean levels of Total Suspended Particles (TSP) of $47 \mu \mathrm{g} / \mathrm{m}^{3}$ with a standard deviation of $26.4 \mu \mathrm{g} / \mathrm{m}^{3}$ and peak value of $138 \mu \mathrm{g} / \mathrm{m}^{3}$ were identified between 2003 and 200458 .

\section{Physical and chemical characteristics of pollutants from industrial activities and motor vehicles}

The physical and chemical characteristics of particles derived from industrial activities and motor vehicles in urban areas in Brazil are summarized in Table 2. The most studied sites in articles on emissions of these pollutants were the metropolitan regions of São Paulo and Rio de Janeiro 7,8,90, 91,94,95,98,99,102,103,105.

In metropolitan areas, $\mathrm{PM}$ is made up of mainly organic elements 95,100 . In the city of Campinas, São Paulo, studies show that $\mathrm{PM}_{2.5}$ is made up of $48 \%$ elemental carbon and $22 \%$ organic carbon 100. The main organic element was BC, representing $18 \%$ to $31 \%$ of $\mathrm{PM}_{2.5}$ in Rio de Janeiro 103 . In the Metropolitan Region of São Paulo, the ionic elements made up $21 \%$ of the chemical composition of $\mathrm{PM}$. $\mathrm{SO}_{4}{ }^{2-}, \mathrm{NO}_{3}$ and $\mathrm{NH}_{4}^{+}$were the most abundant inorganic components in the chemical 
Articles on the physical and chemical characteristics of pollutants from biomass burning in Brazil published between 2000 and 2009.

\begin{tabular}{|c|c|c|c|c|c|}
\hline References & Year & Location & Study period & Pollutants & Results/Chemical composition \\
\hline Yamasoe et al. 75 & 2000 & $\begin{array}{l}\text { Amazon Forest and } \\
\text { Brazilian savanna } \\
\text { (Brasília and } \\
\text { Rondônia State) }\end{array}$ & August/September 1992 & $\mathrm{PM}_{2.5}$ & $\begin{array}{l}\text { 70-92\% of } \mathrm{PM}_{2.5} \text { mass consists of organic } \\
\text { material. Dominant chemical elements: } \mathrm{Cl} \text {-, } \\
\qquad \mathrm{SO}_{4}{ }^{2-}, \mathrm{K}+, \mathrm{BC}\end{array}$ \\
\hline Artaxo et al. 76 & 2000 & $\begin{array}{c}\text { Amazon Forest } \\
\text { (Alta Floresta, Mato } \\
\text { Grosso State) }\end{array}$ & August/September 1995 & $\begin{array}{l}\text { Particles } \\
\text { aerosols }\end{array}$ & $\begin{array}{c}\text { During the drought, the maximum levels of PM } \\
\text { were approximately } 300 \mu \mathrm{g} / \mathrm{m}^{3} \text {. The maximum } \\
\text { concentrations of } \mathrm{BC} \text { were } 17.5 \mu \mathrm{g} / \mathrm{m}^{3}(5-15 \% \\
\text { of aerosol mass). A total of } 56 \% \text { of } \mathrm{PM} \text { mass } \\
\text { is associated with the biomass burning } \\
\text { component. Chemical elements: biomass } \\
\text { burning }(\mathrm{BC}, \mathrm{S}, \mathrm{I}, \mathrm{K}, \mathrm{Br} \text { and } \mathrm{Zn}) \text {; biogenic } \\
\text { components }(\mathrm{P}, \mathrm{K}, \mathrm{Ca}, \mathrm{Mn}, \mathrm{Mg} \text { and Sr); sea salt } \\
\text { component }(\mathrm{NaCl}) ; \text { mining activity components } \\
(\mathrm{Hg})\end{array}$ \\
\hline Artaxo et al. 77 & 2002 & $\begin{array}{l}\text { Amazon Forest and } \\
\text { pasture (Rondônia } \\
\text { State) }\end{array}$ & 1999 & $\begin{array}{l}\mathrm{TSP}, \mathrm{BC}, \mathrm{CO} \\
\text { and } \mathrm{NO}_{2} \\
\mathrm{PM}_{2.5}\end{array}$ & $\begin{array}{l}\text { In the dry season, levels of } \mathrm{PM}_{2.5} \text { ranged from } \\
250 \mu \mathrm{g} / \mathrm{m}^{3}-350 \mu \mathrm{g} / \mathrm{m}^{3} \text {, with an average of } \\
66.9 \mu \mathrm{g} / \mathrm{m}^{3} \text {. The maximum levels of } \mathrm{CO} \text { and } \\
\mathrm{NO}_{2} \text { were } 8 \mathrm{ppm} \text { and } 16 \mathrm{ppb} \text {, respectively. The } \\
\mathrm{BC} \text { concentrations in the } \mathrm{PM}_{2.5} \text { were } 16 \mu \mathrm{g} / \mathrm{m}^{3} \text {. } \\
\text { Twenty one chemical elements were identified, } \\
\text { including: } \mathrm{S}, \mathrm{Al} \text {, Si and K }\end{array}$ \\
\hline Mayol-Bracero et al. 78 & 2002 & $\begin{array}{l}\text { Amazon Forest and } \\
\text { pasture (Rondônia } \\
\text { State) }\end{array}$ & October 1999 & $\begin{array}{l}\mathrm{PM}_{10}, \mathrm{PM}_{2.5} \\
\mathrm{BC}\end{array}$ & $\begin{array}{c}\text { The organic composition of PM was identified } \\
\text { using concentration values of TC, BC, and OC. } \\
\text { TC is composed of approximately } 16 \% \text { BC and } \\
56 \% \text { water-soluble organic carbon }\end{array}$ \\
\hline Maenhaut et al. 12 & 2002 & $\begin{array}{c}\text { Amazon Forest } \\
\text { (Alta Floresta, Mato } \\
\text { Grosso State) }\end{array}$ & 1996 to 1998 & $\begin{array}{l}\mathrm{PM}_{10} \mathrm{PM}_{2.5} \\
\mathrm{BC}\end{array}$ & $\begin{array}{l}\text { In dry season, the levels of } \mathrm{PM}_{2.5} \text { and } \mathrm{PM}_{10} \\
\text { ranged from } 20 \mu \mathrm{g} / \mathrm{m}^{3} \text { to } 200 \mu \mathrm{g} / \mathrm{m}^{3} \text { and } 15 \mu \mathrm{g} / \\
\mathrm{m}^{3} \text { to } 80 \mu \mathrm{g} / \mathrm{m}^{3} \text {, respectively. The average } \\
\text { concentrations of } \mathrm{PM}_{10} \text { and } \mathrm{PM}_{2.5} \text { ranged from } \\
37 \pm 25 \text { and } 63 \pm 55 \mu \mathrm{g} / \mathrm{m}^{3} \text {. On average, } 67 \% \text { of } \\
\mathrm{PM}_{2.5} \text { are derived from biomass burning. The } \\
\text { main chemical elements in } \mathrm{PM}_{2.5} \text { in biomass } \\
\text { burning are: } \mathrm{BC}, \mathrm{K}, \mathrm{S}, \mathrm{Zn}, \mathrm{Rb} \text { and } \mathrm{Br}\end{array}$ \\
\hline Graham et al. 79 & 2003 & Amazon Forest & July 2001 & $\begin{array}{l}\mathrm{PM}_{10} \text { and } \\
\mathrm{PM}_{2,5}\end{array}$ & $\begin{array}{l}\text { On average, } 16 \% \text { of the } \mathrm{OC} \text { in the } \mathrm{PM}_{2.5} \text { was } \\
\text { due to biomass burning }\end{array}$ \\
\hline Guyon et al. 13 & 2004 & $\begin{array}{l}\text { Amazon Forest and } \\
\text { pasture (Rondônia } \\
\text { State) }\end{array}$ & 1999 & $\begin{array}{l}\mathrm{PM}_{10}, \mathrm{PM}_{2.5}, \\
\mathrm{BC}\end{array}$ & $\begin{array}{l}19 \text { trace elements were identified. In dry } \\
\text { season, the PCA identified three components: } \\
\text { (1) Biomass burning and soil dust BC, Si, P, S, K, } \\
\text { Mn, Fe, Zn; (2) Biogenic aerosols P, S, K; and (3) } \\
\text { Soil dust Fe and Mn }\end{array}$ \\
\hline Allen et al. 80 & 2004 & $\begin{array}{l}\text { Sugarcane } \\
\text { (Araraquara, São } \\
\text { Paulo State) }\end{array}$ & 1999 to 2001 & $\begin{array}{l}\mathrm{PM}_{10} \text { and } \\
\mathrm{PM}_{2.5}\end{array}$ & $\begin{array}{l}\text { For sugarcane burning plumes } \mathrm{Na}^{+}, \mathrm{NH}_{4}{ }^{+}, \\
\mathrm{HCOO}, \mathrm{CH}_{3} \mathrm{COO}-, \mathrm{Cl} \text { - and } \mathrm{NO}_{3}-\text { were present } \\
\text { at higher concentrations in fine fractions }\end{array}$ \\
\hline Trebs et al. 81 & 2005 & $\begin{array}{l}\text { Amazon Forest and } \\
\text { pasture (Rondônia } \\
\text { State) }\end{array}$ & $\begin{array}{l}\text { September/November } \\
2002\end{array}$ & $\mathrm{PM}_{2.5}$ & $\begin{array}{l}\text { The contribution of ionic components in } \\
\text { the fractions was below } 20 \% \text {, indicating a } \\
\text { predominance of organic material }\end{array}$ \\
\hline Artaxo et al. 82 & 2005 & $\begin{array}{c}\text { Amazon Forest } \\
\text { (Alta Floresta, Mato } \\
\text { Grosso State) }\end{array}$ & 1992 to 2002 & $\begin{array}{l}\mathrm{PM}_{10}, \mathrm{PM}_{2.5}, \\
\mathrm{BC}\end{array}$ & $\begin{array}{l}\text { The concentrations of inhalable particles } \\
\text { ranged between } 100 \mu \mathrm{g} / \mathrm{m}^{3} \text { to } 600 \mu \mathrm{g} / \mathrm{m}^{3}\end{array}$ \\
\hline
\end{tabular}

(continues) 
Table 1 (continued)

\begin{tabular}{|c|c|c|c|c|c|}
\hline References & Year & Location & Study period & Pollutants & Results/Chemical composition \\
\hline Mahowald et al. 83 & 2005 & $\begin{array}{l}\text { Amazon Forest } \\
\text { and pasture (Alta } \\
\text { Floresta, Mato } \\
\text { Grosso State and } \\
\text { Rondônia State) }\end{array}$ & 1996 to 2002 & $\begin{array}{l}\mathrm{PM}_{2.5} \text { and } \\
\mathrm{PM}_{10}\end{array}$ & $\begin{array}{l}\text { Biomass burning is responsible for } 23 \% \text { of the } \\
\text { flow of phosphorus in the Brazilian Amazon. } \\
\text { In the chemical speciation of PM } 21 \text { elements } \\
\text { were identified, including: } \mathrm{Mg}, \mathrm{Al}, \mathrm{Si}, \mathrm{P}, \mathrm{S}, \mathrm{Cl} \text {, } \\
\qquad \mathrm{K}, \mathrm{Ca}, \mathrm{Ti}, \mathrm{V}, \mathrm{Fe}, \mathrm{Zn} \text { and } \mathrm{Cu}\end{array}$ \\
\hline Lara et al. 84 & 2005 & $\begin{array}{l}\text { Sugarcane } \\
\text { (Piracicaba, São } \\
\text { Paulo State) }\end{array}$ & 1997 to 1998 & $\begin{array}{c}\mathrm{PM}_{10}, \mathrm{PM}_{2.5} \\
\text { and } \mathrm{BC}\end{array}$ & $\begin{array}{c}\mathrm{PM}_{10} \text { concentrations ranged between } \\
9.3 \mu \mathrm{g} / \mathrm{m}^{3} \text { to } 238 \mu \mathrm{g} / \mathrm{m}^{3} \text {. The sugarcane is the } \\
\text { main source of } \mathrm{PM}_{2.5}, \text { representing } 60 \% \text { of } \\
\mathrm{PM}_{2.5} \text {. The levels of } \mathrm{PM}_{2.5}, \mathrm{PM}_{10} \text { and } \mathrm{BC} \text { were } \\
\text { highest during the dry season. In the chemical } \\
\text { speciation of } \mathrm{PM} 21 \text { elements were identified, } \\
\text { including: } \mathrm{BC}, \mathrm{Al}, \mathrm{Si}, \mathrm{P}, \mathrm{S}, \mathrm{Cl}, \mathrm{K}, \mathrm{Cr}, \mathrm{Mn}, \mathrm{Cu}, \mathrm{Zn} \\
\text { and } \mathrm{Pb}\end{array}$ \\
\hline Chand et al. 85 & 2006 & $\begin{array}{l}\text { Amazon Forest and } \\
\text { pasture (Rondônia } \\
\text { State) }\end{array}$ & $\begin{array}{l}\text { September/November } \\
\qquad 2002\end{array}$ & $\mathrm{PM}_{2.5}$ and $\mathrm{CO}$ & $\begin{array}{l}\text { The levels of } \mathrm{PM}_{2.5} \text { ranged from } 2 \mu \mathrm{g} / \mathrm{m}^{3} \text { to } \\
225 \mu \mathrm{g} / \mathrm{m}^{3} \text { and from } 300-3,500 \mathrm{ppb} \text { for } \mathrm{CO}\end{array}$ \\
\hline Cançado et al. 52 & 2006 & $\begin{array}{l}\text { Sugarcane } \\
\text { (Piracicaba, São } \\
\text { Paulo State) }\end{array}$ & 1997 to 1998 & $\mathrm{PM}_{2.5}$ & $\begin{array}{l}\text { In the chemical speciation of PM, } 21 \text { elements } \\
\text { were identified, including; } \mathrm{Al}, \mathrm{Si}, \mathrm{P}, \mathrm{S}, \mathrm{Cl}, \mathrm{K} \text {, } \\
\mathrm{P}, \mathrm{Ca}, \mathrm{Ti}, \mathrm{Cr}, \mathrm{Cu}, \mathrm{Ni}, \mathrm{Zn} \text {. Chemical elements } \\
\text { related to biomass burning component: } \mathrm{Si}, \mathrm{S} \text {, } \\
\qquad \mathrm{K}, \mathrm{Cl}, \mathrm{Fe}, \mathrm{Br}\end{array}$ \\
\hline Arbex et al. 58 & 2007 & $\begin{array}{l}\text { Sugarcane } \\
\text { (Piracicaba, São } \\
\text { Paulo State) }\end{array}$ & 2003 to 2004 & TSP & $\begin{array}{c}\text { The average concentration was } 46.8 \mu \mathrm{g} / \mathrm{m}^{3} \text {. } \\
\text { Minimum and maximum values were between } \\
6.7 \mu \mathrm{g} / \mathrm{m}^{3} \text { and } 137.8 \mu \mathrm{g} / \mathrm{m}^{3}\end{array}$ \\
\hline Fuzzi et al. 86 & 2007 & $\begin{array}{l}\text { Amazon Forest } \\
\text { (Rondônia State) }\end{array}$ & $\begin{array}{l}\text { September/November } \\
2002\end{array}$ & $\mathrm{PM}_{10}$ and $\mathrm{CO}$ & $\begin{array}{c}\text { In the dry season, aerosols were predominately } \\
\text { composed of organic elements, only } 10 \% \text { of } \\
\text { soluble inorganic salts. Sulphates were the } \\
\text { main anions }\end{array}$ \\
\hline Pauliquevis et al. 87 & 2007 & $\begin{array}{l}\text { Amazon Forest } \\
\text { (Balbina, Amazonas } \\
\text { State) }\end{array}$ & 1998 to 2002 & $\begin{array}{l}\mathrm{PM}_{10} \text { and } \\
\mathrm{PM}_{2.5}\end{array}$ & $\begin{array}{l}\text { The average concentrations of } \mathrm{PM}_{2.5} \text { and } \mathrm{PM}_{10} \\
\text { ranged from } 62 \mu \mathrm{g} / \mathrm{m}^{3} \text { to } 31 \mu \mathrm{g} / \mathrm{m}^{3} \text { and } 72 \mu \mathrm{g} / \mathrm{m}^{3} \\
\text { to } 21 \mu \mathrm{g} / \mathrm{m}^{3} \text {, respectively. Chemical elements in } \\
\text { the } \mathrm{PM}_{2.5}: \mathrm{BC}, \mathrm{K}, \mathrm{S}, \mathrm{Al}, \mathrm{Si}, \mathrm{P}\end{array}$ \\
\hline Mascarenhas et al. 65 & 2008 & $\begin{array}{l}\text { Amazon Forest (Rio } \\
\text { Branco, Acre State) }\end{array}$ & September 2005 & $\mathrm{PM}_{2.5}$ & $\begin{array}{l}\text { The values for } \mathrm{PM}_{2.5} \text { exceeded the quality } \\
\text { standard during } 23 \text { days in September } 2005 \text {, } \\
\text { with maximum values reaching } 450 \mu \mathrm{g} / \mathrm{m}^{3}\end{array}$ \\
\hline
\end{tabular}

BC: black carbon; OC: organic carbon; PCA: principal components analysis; PM: particulate matter; TC: total carbon; TSP: total suspended particles.

constitution of $\mathrm{PM}_{2.5}$. In the makeup of $\mathrm{PM}_{2.5-10}$ and $\mathrm{PM}_{2.5}, \mathrm{NO}_{3}$ and $\mathrm{SO}_{4} 2$ - represented $60 \%$ of the inorganic compounds in $\mathrm{PM}_{2.5}$. The concentration of sulphates was $38 \%$ higher in fine fractions than in course fractions 98 .

In metropolitan areas in the South and Southeast Regions of Brazil, high concentrations of metals, especially $\mathrm{Zn}, \mathrm{Pb}, \mathrm{Cr}$, manganese (Mn) and cadmium (Cd) were measured in PM 8,101,102. In Rio de Janeiro, elevated concentrations of calcium (Ca), magnesium (Mg), Fe, aluminum (Al) and $\mathrm{Zn}$ were identified in the elemental composition of $\mathrm{PM}_{2.5}$. The presence of $\mathrm{Cd}$, nickel (Ni), $\mathrm{Pb}$ and $\mathrm{Cu}$ is related to emissions from industry and motor vehicles 102 . In steel manufacturing regions in the state of Rio de Janeiro, $\mathrm{Pb}$ concentrations reached values of $140 \mathrm{ng} / \mathrm{m}^{3}$ in the elemental composition of PM 107.

Polycyclic Aromatic Hydrocarbons (PAHs) were also detected in the chemical composition of PM emitted in metropolitan areas. In Volta Redonda, Rio de Janeiro State, high concentrations of PAHs, such as benzene $\left(52-93 \mu \mathrm{g} / \mathrm{m}^{3}\right)$, toluene $\left(17-30 \mu \mathrm{g} / \mathrm{m}^{3}\right)$ and xylene $\left(1.7-3 \mu \mathrm{g} / \mathrm{m}^{3}\right)$ were found ${ }^{8}$. In the Southern Region of Brazil, in areas with substantial industrial activity, such as Porto Alegre, the mean value of PAHs ranged between $0.04 \mu \mathrm{g} / \mathrm{m}^{3}$ and $2.3 \mu \mathrm{g} / \mathrm{m}^{3}$ with 
Articles on the physical and chemical characteristics of pollutants from industrial activities and vehicles in Brazil published between 2000 and 2009.

\begin{tabular}{|c|c|c|c|c|c|}
\hline References & Year & Location & Study period & Pollutants & Results/Chemical elements \\
\hline Castanho \& Artaxo 7 & 2001 & $\begin{array}{l}\text { Metropolitan } \\
\text { region of São } \\
\text { Paulo }\end{array}$ & $\begin{array}{c}\text { June/September 1997, } \\
\text { January/March } 1998\end{array}$ & $\begin{array}{l}\mathrm{PM}_{10} \text { and } \\
\mathrm{PM}_{2.5}\end{array}$ & $\begin{array}{l}\text { Motor vehicles represented } 28 \% \text { and } \\
24 \% \text { of the } \mathrm{PM}_{2.5} \text { in winter and summer, } \\
\text { respectively. In the winter, the } \mathrm{PM}_{2.5} \text { consist } \\
\text { of } 40 \pm 16 \% \text { organic carbon, } 21 \pm 4 \% \mathrm{BC} \text {, } \\
20 \pm 10 \% \text { ammonium sulfates and } 12 \pm 2 \% \text { soil } \\
\text { components }\end{array}$ \\
\hline Gioda et al. 8 & 2004 & $\begin{array}{l}\text { Volta Redonda/Rio } \\
\text { de Janeiro State }\end{array}$ & $\begin{array}{c}1995 \text { to } 1996 \text { and April/ } \\
\text { May } 1999\end{array}$ & $\begin{array}{l}\mathrm{TSP} \mathrm{PM}_{10} \\
\text { benzene, } \\
\text { toluene, } \\
\text { xylene, } \mathrm{SO}_{2}\end{array}$ & $\begin{array}{c}\text { Average daily concentrations: TSP }(54-163 \mu \mathrm{g} / \\
\left.\mathrm{m}^{3}\right), \mathrm{PM}_{10}\left(44 \mu \mathrm{g} / \mathrm{m}^{3} \text { to } 78 \mu \mathrm{g} / \mathrm{m}^{3}\right) \text {, benzene } \\
\left(52 \mu \mathrm{g} / \mathrm{m}^{3} \text { to } 93 \mu \mathrm{g} / \mathrm{m}^{3}\right) \text {, toluene }\left(17 \mu \mathrm{g} / \mathrm{m}^{3}\right. \\
\left.\text { to } 30 \mu \mathrm{g} / \mathrm{m}^{3}\right) \text {, xylene }\left(1.7-3 \mu \mathrm{g} / \mathrm{m}^{3}\right) \text { and } \mathrm{SO}_{2} \\
\left(186 \mu \mathrm{g} / \mathrm{m}^{3}\right) \text {. High concentration elements: } \mathrm{Pb} \text {, } \\
\mathrm{Cr} \text {, and } \mathrm{Zn}\end{array}$ \\
\hline Bertran et al. 88 & 2004 & $\begin{array}{l}\text { Institute for } \\
\text { Technological } \\
\text { Research of São } \\
\text { Paulo }\end{array}$ & - & PM & $\begin{array}{l}\text { Particle shape: spherical, very compact and } \\
\text { smooth cenospheres with sizes of } 0.6 \mu \mathrm{m} \\
\text { to } 1.5 \mu \mathrm{m} \text {. The elements } \mathrm{Al}, \mathrm{Si}, \mathrm{S} \text { and } \mathrm{V} \text { had } \\
\text { higher concentrations }\end{array}$ \\
\hline Braga et al. 89 & 2004 & $\begin{array}{l}\text { Candiota region, } \\
\text { Rio Grande do Sul } \\
\text { State }\end{array}$ & 2000 to 2001 & $\begin{array}{l}\mathrm{PM}_{10}, \mathrm{PM}_{2.5-10} \\
\text { and } \mathrm{PM}_{2.5}\end{array}$ & $\begin{array}{l}\text { Average concentration: } \mathrm{PM}_{10} \text { was } 13.09 \mu \mathrm{g} / \\
\mathrm{m}^{3} \text { for } \mathrm{HV} \text { and } 14.85 \mu \mathrm{g} / \mathrm{m}^{3} \text { for Dichotomous. } \\
\text { The maximum values were } 40.17 \mu \mathrm{g} / \mathrm{m}^{3} \text { in the } \\
\text { Pedras Altas station. Levels of } \mathrm{PM}_{2.5-10} \text { and } \\
\mathrm{PM}_{2.5} \text { were } 9.66 \text { and } 5.19 \mu \mathrm{g} / \mathrm{m}^{3} \text {, respectively }\end{array}$ \\
\hline Quitério et al. 90 & 2004 & $\begin{array}{l}\text { Industrial region of } \\
\text { Santa Cruz/Rio de } \\
\text { Janeiro }\end{array}$ & 2001 to 2002 & TSP & $\begin{array}{c}\text { The geometrical mean of TSP ranged } \\
\text { between } 87 \mu \mathrm{g} / \mathrm{m}^{3} \text { and } 40 \mu \mathrm{g} / \mathrm{m}^{3} \text {. } \\
\text { Concentration levels of metals were high. } \\
\text { Chemical elements from components } \\
\text { analysis: metallurgical activity (TSP, Ca, Mo, } \\
\text { Mn, } \mathrm{Fe}, \mathrm{Zn}, \mathrm{Cu} \text { and } \mathrm{Ni} \text { ) and steel industries } \\
\text { (Mg, } \mathrm{K} \text { and } \mathrm{Al})\end{array}$ \\
\hline Miranda et al. 91 & 2005 & $\begin{array}{l}\text { Metropolitan } \\
\text { region of São } \\
\text { Paulo }\end{array}$ & July/August 2002 & $\begin{array}{c}\mathrm{NO}_{2}, \mathrm{PM}_{10} \\
\mathrm{PM}_{2.5} \text {, and } \mathrm{O}_{3}\end{array}$ & $\begin{array}{l}\text { Concentrations of } 24 \mathrm{~h} \mathrm{PM}_{10} \text { exceed the } \\
\text { national standard of } 150 \mu \mathrm{g} / \mathrm{m}^{3} \text {. The principal } \\
\text { elements detected in } \mathrm{PM}_{2.5} \text { were: } \mathrm{S}, \mathrm{K}, \mathrm{Al} \text { and } \\
\mathrm{Fe} \text {, soil dust and combustion products }\end{array}$ \\
\hline Dallarosa et al. 92 & 2005 & $\begin{array}{l}\text { Metropolitan } \\
\text { region of Porto } \\
\text { Alegre, Rio } \\
\text { Grande do Sul } \\
\quad \text { State }\end{array}$ & 2001 to 2002 & $\begin{array}{l}\mathrm{PM}_{10} \text { and } \\
\mathrm{PAHs}\end{array}$ & $\begin{array}{c}\text { The } \mathrm{PM}_{10} \text { levels ranged between } 7.37 \mu \mathrm{g} / \\
\mathrm{m}^{3} \text { and } 89.7 \mu \mathrm{g} / \mathrm{m}^{3} \text {. Fourteen PAHs were } \\
\text { identified. The average concentrations } \\
\text { ranged between } 0.04 \mu \mathrm{g} / \mathrm{m}^{3} \text { and } 2.3 \mu \mathrm{g} / \mathrm{m}^{3} \text {. } \\
\text { The benzo(ghi)perileno (BGP) showed the } \\
\text { highest concentrations }\end{array}$ \\
\hline Braga et al. 93 & 2005 & $\begin{array}{l}\text { Rio Grande do Sul } \\
\text { State }\end{array}$ & 2001 to 2002 & $\begin{array}{l}\mathrm{PM}_{10} \text { and } \\
\mathrm{PM}_{2.5}\end{array}$ & $\begin{array}{l}\text { The average concentrations of } \mathrm{PM}_{10} \text { and } \\
\mathrm{PM}_{2.5} \text { ranged from } 5 \mu \mathrm{g} / \mathrm{m}^{3} \text { to } 115 \mu \mathrm{g} / \mathrm{m}^{3} \\
\text { and from } 1 \mu \mathrm{g} / \mathrm{m}^{3} \text { to } 44 \mu \mathrm{g} / \mathrm{m}^{3} \text {, respectively. } \\
\mathrm{S}, \mathrm{Cl}, \mathrm{S}, \mathrm{V}, \mathrm{Cr}, \mathrm{Mn}, \mathrm{Ni}, \mathrm{Cu} \text { and } \mathrm{Zn} \text { have high } \\
\text { emission factor related to the } \mathrm{PM}_{2.5}\end{array}$ \\
\hline $\begin{array}{l}\text { Carvalho-Oliveira } \\
\text { et al. } 94\end{array}$ & 2005 & $\begin{array}{l}\text { Metropolitan } \\
\text { region of São } \\
\quad \text { Paulo }\end{array}$ & April 2003 & $\begin{array}{l}\mathrm{PM}_{2.5} \text { and } \\
\mathrm{PAHs}\end{array}$ & $\begin{array}{l}\text { Chemical elements in the } \mathrm{PM}_{2.5} \text { : } \mathrm{As}, \mathrm{Br} \text {, } \\
\mathrm{Co}, \mathrm{Cl}, \mathrm{Fe}, \mathrm{La}, \mathrm{Mn}, \mathrm{Sb}, \mathrm{Sc} \text { and } \mathrm{Th} \text {. PAHs: } \\
\text { benzene, toluene, etil-benzene e xylene. The } \\
\text { concentrations were higher for nonstrike days }\end{array}$ \\
\hline
\end{tabular}

(continues) 
Table 2 (continued)

\begin{tabular}{|c|c|c|c|c|c|}
\hline References & Year & Location & Study period & Pollutants & Results/Chemical elements \\
\hline Miranda et al. 95 & 2005 & $\begin{array}{l}\text { Metropolitan } \\
\text { region of São } \\
\text { Paulo }\end{array}$ & 1999 to 2000 & PM & $\begin{array}{c}\text { The mass distribution has two modes: } 0.8 \mu \mathrm{m} \\
\text { and } 8 \mu \mathrm{m} \text {. PM is composed mainly of organic } \\
\text { elements: } \mathrm{BC} \text { elements derived from soil as } \\
\text { well as } \mathrm{S}, \mathrm{Br} \text { and } \mathrm{Cu}\end{array}$ \\
\hline Pereira et al. 96 & 2007 & $\begin{array}{c}\text { Bus station, } \\
\text { Salvador, Bahia } \\
\text { State }\end{array}$ & $\begin{array}{l}\text { September/October } \\
2004 \text { and July } 2005\end{array}$ & TSP and $\mathrm{PM}_{10}$ & $\begin{array}{l}\text { The maximum levels of TSP and } \mathrm{PM}_{10} \\
\text { ranged between } 16.9 \mu \mathrm{g} / \mathrm{m}^{3} \text { to } 354 \mu \mathrm{g} / \mathrm{m}^{3} \\
\text { and } 13.9 \mu \mathrm{g} / \mathrm{m}^{3} \text { to } 393 \mu \mathrm{g} / \mathrm{m}^{3} \text {, respectively. } \mathrm{Zn} \\
\text { and } \mathrm{Cu} \text { were the main elements related to } \\
\text { anthropogenic sources. Fe had the highest } \\
\text { concentration, with minimum and maximum } \\
\text { values of } 7.03 \mathrm{ng} \cdot \mathrm{m}^{-3} \text { and } 650 \mathrm{ng} \cdot \mathrm{m}^{-3}\end{array}$ \\
\hline Queiroz et al. 97 & 2007 & $\begin{array}{c}\text { Sete Lagoas, } \\
\text { Minas Gerais State }\end{array}$ & January/February 2005 & TSP and $\mathrm{PM}_{10}$ & $\begin{array}{l}\text { In } 53 \% \text { of days sampled, the } \mathrm{PM}_{10} \text { values } \\
\text { exceeded } 50 \mu \mathrm{g} / \mathrm{m}^{3}\left(16-132 \mu \mathrm{g} / \mathrm{m}^{3}\right) \text {. } \\
\text { Components analysis of } \mathrm{PM}_{10}: \mathrm{Al}, \mathrm{Ba}, \mathrm{Cr} \text {, } \\
\mathrm{Fe}, \mathrm{Dy}, \mathrm{Mg}, \mathrm{Mn}, \mathrm{Na}, \mathrm{V} \text { and } \mathrm{Zn} \text {. Sources } \\
\text { of emission: iron, concrete and ceramic } \\
\text { production }\end{array}$ \\
\hline Bourotte et al. 98 & 2007 & $\begin{array}{l}\text { Metropolitan } \\
\text { region of São } \\
\text { Paulo }\end{array}$ & May/July 2002 & $\begin{array}{l}\mathrm{PM}_{2.5-10} \text { and } \\
\mathrm{PM}_{2.5}\end{array}$ & $\begin{array}{l}\text { The concentrations of } \mathrm{PM}_{2.5-10} \text { and } \mathrm{PM}_{2.5} \\
\text { ranged between } 4.13 \mu \mathrm{g} / \mathrm{m}^{3} \text { and } 62 \mu \mathrm{g} / \mathrm{m}^{3} \text { and } \\
2.82 \mu \mathrm{g} / \mathrm{m}^{3} \text { to } 26.6 \mu \mathrm{g} / \mathrm{m}^{3} \text {, respectively. The } \\
\text { inorganic elements make up } 21 \% \text { of } \mathrm{PM}_{2.5} \text {. } \\
\text { Chemical components: } \mathrm{PM}_{2.5}\left(\mathrm{SO}_{4}^{2-}, \mathrm{NO}_{3}-\text {, }\right. \\
\left.\mathrm{NH}^{+}{ }_{4}\right) \text { and } \mathrm{PM}_{2.5-10}\left(\mathrm{NO}_{3}^{-}, \mathrm{SO}_{4}{ }^{2-}, \mathrm{Ca}^{2+} \text { and }\right. \\
\mathrm{Cl} \text {-). } \mathrm{NO}_{3} \text { - and } \mathrm{SO}_{4}{ }^{2-} \text { were predominant and } \\
\text { greater than } 60 \% . \mathrm{SO}_{4}{ }^{2-} \text { was } 38 \% \text { higher in } \\
\mathrm{PM}_{2.5} . \mathrm{NH}_{4} \text { - was } 13 \text { times higher in the } \mathrm{PM}_{2.5}\end{array}$ \\
\hline Silva et al. 99 & 2008 & $\begin{array}{l}\text { Metropolitan } \\
\text { region of Rio de } \\
\text { Janeiro }\end{array}$ & 2005 & $\mathrm{PM}_{10}$ & $\begin{array}{l}\text { Chemical elements: } \mathrm{Cd}, \mathrm{Ce}, \mathrm{Cu}, \mathrm{La}, \mathrm{Mo}, \mathrm{Ni} \text {, } \\
\mathrm{Pb}, \mathrm{Pd}, \mathrm{Rh}, \mathrm{Sb} \text { and } \mathrm{Sn} . \mathrm{Mo}, \mathrm{Pd} \text { and } \mathrm{Rh} \text { were } \\
\text { due to pollution arising from the degradation } \\
\text { of auto catalysts }\end{array}$ \\
\hline Miranda et al. 100 & 2008 & $\begin{array}{c}\text { Campinas, São } \\
\text { Paulo State }\end{array}$ & $\begin{array}{c}\text { December } 2003 \text { and } \\
\text { August } 2004\end{array}$ & $\begin{array}{c}\mathrm{PM}_{10} \\
\mathrm{PM}_{2.5-10} \text { and } \\
\mathrm{PM}_{2.5}\end{array}$ & $\begin{array}{c}\text { Average annual concentrations: } \mathrm{PM}_{10} \\
\left(20.85 \mu \mathrm{g} / \mathrm{m}^{3}\right), \mathrm{PM}_{2.5-10}\left(10.17 \mu \mathrm{g} / \mathrm{m}^{3}\right) \text { and } \\
\mathrm{PM}_{2.5}\left(10.68 \mu \mathrm{g} / \mathrm{m}^{3}\right) . \mathrm{PM}_{2.5} \text { is composed of } \\
48 \% \text { carbon elements, } 22 \% \text { organic carbon. } \\
\text { Chemical elements: } \mathrm{Al}, \mathrm{V}, \mathrm{S}, \mathrm{Mn}, \mathrm{SO}_{2}, \mathrm{Fe}, \mathrm{Zn} \text {, } \\
\mathrm{K}, \mathrm{H}_{2} \mathrm{SO}_{4}\end{array}$ \\
\hline Godói et al. 101 & 2008 & $\begin{array}{c}\text { Metropolitan } \\
\text { region of Curitiba, } \\
\text { Paraná State }\end{array}$ & $\begin{array}{c}\text { December } 2005 \text { and } \\
\text { January } 2006\end{array}$ & PM & $\begin{array}{l}\text { Chemical elements: } \mathrm{Al}, \mathrm{Si}, \mathrm{Fe}, \mathrm{S}, \mathrm{Cl}, \mathrm{K} \text { and } \\
\text { Ca arising from biomass burning, soil or } \\
\text { limestone particles; } \mathrm{Ti}, \mathrm{Cr} \text { and } \mathrm{Mn} \text { arising } \\
\text { from limestone and silica rocks; } \mathrm{Zn} \text { and } \mathrm{Cu} \\
\text { released from wood combustion or vehicles }\end{array}$ \\
\hline Toledo et al. 102 & 2008 & $\begin{array}{l}\text { Metropolitan } \\
\text { region of Rio de } \\
\text { Janeiro }\end{array}$ & $\begin{array}{c}\text { September } 2004 \text { and } \\
\text { August } 2005\end{array}$ & TPS and $\mathrm{PM}_{10}$ & $\begin{array}{l}\text { The average levels of } \mathrm{PM}_{10} \text { ranged between } \\
42 \mu \mathrm{g} / \mathrm{m}^{3} \text { and } 169 \mu \mathrm{g} / \mathrm{m}^{3} \text { for the period. The } \\
\text { maximum value was } 312 \mu \mathrm{g} / \mathrm{m}^{3} . \text { In } \mathrm{PM}_{10} \text { high } \\
\text { concentrations of } \mathrm{Ca}, \mathrm{Mg}, \mathrm{Fe}, \mathrm{Al} \text { and } \mathrm{Zn} \text { were } \\
\text { identified. } \mathrm{Cd}, \mathrm{Ni}, \mathrm{Pb} \text { and } \mathrm{Cu} \text { were released } \\
\text { from industrial activity and vehicles }\end{array}$ \\
\hline
\end{tabular}

(continues) 


\begin{tabular}{|c|c|c|c|c|c|}
\hline References & Year & Location & Study period & Pollutants & Results/Chemical elements \\
\hline Godoy et al. 103 & 2009 & $\begin{array}{l}\text { Metropolitan } \\
\text { region of Rio de } \\
\text { Janeiro }\end{array}$ & $\begin{array}{l}\text { September } 2003 \text { and } \\
\text { December } 2005\end{array}$ & $\begin{array}{l}\mathrm{PM}_{10} \text { and } \\
\mathrm{PM}_{2.5}\end{array}$ & $\begin{array}{l}48 \text { chemical elements were identified in } \mathrm{PM} \text {. } \\
\mathrm{BC} \text { made up } 18-31 \% \text { of } \mathrm{PM}_{2.5} \text {. Chemical } \\
\text { elements in the } \mathrm{PM}_{2.5} \text { : soil dust ( } \mathrm{Al}, \mathrm{K}, \mathrm{Fe} \text { and } \\
\mathrm{Ce} \text { ); vehicles }(\mathrm{As}, \mathrm{Cu}, \mathrm{Cd}, \mathrm{Sb}, \mathrm{Pb} \text { and } \mathrm{BC}) \text {; oil } \\
\left.\text { combustion ( } \mathrm{Ni}, \mathrm{V} \text { and } \mathrm{SO}_{4}{ }^{2-}\right) \text {; evaporation } \\
\text { from the sea }(\mathrm{Na} \text { and } \mathrm{Mg})\end{array}$ \\
\hline Teixeira et al. 104 & 2009 & $\begin{array}{l}\text { Rio Grande do Sul } \\
\text { State }\end{array}$ & 2003 to 2004 & $\begin{array}{c}\mathrm{PM}_{10}, \mathrm{PM}_{2.5-10} \\
\text { and } \mathrm{PM}_{2.5}\end{array}$ & $\begin{array}{l}22 \text { chemical elements were identified. } \\
\text { The } \mathrm{PM}_{2.5} / \mathrm{PM}_{10} \text { ratio was less than } 50 \% \text {. } \\
\text { Course mode chemical elements: } \mathrm{Al}, \mathrm{Si}, \mathrm{Ca} \text {, } \\
\mathrm{Mg}, \mathrm{Ti}, \mathrm{K}, \mathrm{Na} \text { and } \mathrm{Fe} \text {. In } \mathrm{PM}_{2.5}, \mathrm{~S} \text { had the } \\
\text { highest concentrations. } \mathrm{PM}_{2.5} \text { had a higher } \\
\text { concentration of } \mathrm{Cr}, \mathrm{Co}, \mathrm{Zn}, \mathrm{Ni} \text { and } \mathrm{Cu} \text { than } \\
\text { the } \mathrm{PM}_{2.5-10} \text { particles }\end{array}$ \\
\hline $\begin{array}{l}\text { Sánchez-Ccoyllo } \\
\text { et al. } 105\end{array}$ & 2009 & $\begin{array}{c}\text { São Paulo City } \\
\text { Tunnel }\end{array}$ & March/May 2004 & $\begin{array}{c}\mathrm{PM}_{10} \\
\mathrm{PM}_{2.5-10} \\
\mathrm{PM}_{2.5} \text { and } \mathrm{BC}\end{array}$ & $\begin{array}{l}\mathrm{BC} \text { emission for } \mathrm{PM}_{10}, \mathrm{PM}_{2.5-10} \text { and } \mathrm{PM}_{2.5} \\
\text { was } 29 \mathrm{x}, 4 \mathrm{x} \text { e } 6 \mathrm{x} \text { times higher for heavy-duty } \\
\text { metals than for light-duty vehicles. Chemical } \\
\text { elements: } \mathrm{Fe}, \mathrm{Br}, \mathrm{Al}, \mathrm{Si}, \mathrm{S}, \mathrm{Cu}, \mathrm{Zn} \text { and } \mathrm{Pb} \text {. } \mathrm{Fe} \text {, } \\
\mathrm{Al} \text { and } \mathrm{S} \text { had the highest concentrations }\end{array}$ \\
\hline Jacomino et al. 106 & 2009 & $\begin{array}{c}\text { Sete Lagoas, } \\
\text { Minas Gerais State }\end{array}$ & $\begin{array}{l}\text { January and February } \\
\qquad 2005\end{array}$ & $\mathrm{PM}_{10}$ & $\begin{array}{l}\text { The concentrations of } \mathrm{PM}_{10} \text { ranged between } \\
16 \mu \mathrm{g} / \mathrm{m}^{3} \text { and } 132 \mu \mathrm{g} / \mathrm{m}^{3} \text { for the period. } \\
\text { Components analysis of } \mathrm{PM}_{10} \text { : soil and } \\
\text { asphalt dust }(\mathrm{Sc}, \mathrm{Th}, \mathrm{Fe}, \mathrm{Ba}, \mathrm{Zn}) \text {; industries } \\
\text { activity }(\mathrm{Ga}, \mathrm{Na}, \mathrm{Al} \text { and } \mathrm{V}) \text {; asphalt dust or } \\
\text { industrial processes ( } \mathrm{Dy} \text { and } \mathrm{Cr} \text { ). Dominant } \\
\text { chemical elements in } \mathrm{PM}_{10}: \mathrm{Na}, \mathrm{Fe}, \mathrm{Cl} \text { and } \mathrm{Ba}\end{array}$ \\
\hline
\end{tabular}

BC: black carbon; PAH: polycyclic aromatic hydrocarbons; PM: particulate matter; TSP: total suspended particles.

benzo(ghi)perylene (BGP) having the highest concentration 92 .

In the metropolitan region of São Paulo, combustion of diesel and gasoline made up $28 \%$ of emissions of $\mathrm{PM}_{2.5}$ during the winter 7. In São Paulo, the average level of $\mathrm{PM}_{2.5}$ was $54 \mu \mathrm{g} / \mathrm{m}^{3}$, with a peak of $186.2 \mu \mathrm{g} / \mathrm{m}^{3}$ between 1996 and 2000 49. In Rio de Janeiro, the average concentration of $\mathrm{PM}_{10}$ was $84.7 \mu \mathrm{g} / \mathrm{m}^{3}$, with a peak of $199 \mu \mathrm{g} / \mathrm{m}^{3}$ in 200470 . The average level of $\mathrm{PM}_{10}$ in Rio de Janeiro ranged between $42 \mu \mathrm{g} / \mathrm{m}^{3}$ and $169 \mu \mathrm{g} / \mathrm{m}^{3}$ between 2004 and 2005102.

\section{Types of studies, health outcomes and susceptible groups}

Articles about air pollution, with emphasis on $\mathrm{PM}_{2.5}$ and its effects on human health in Brazil were analyzed using the following criteria: study site, subject group and health outcomes (Table $3)$. Of the 54 articles selected, 33 (61\%) 21,22,23,25, $26,27,28,29,31,32,33,34,35,36,37,38,41,43,44,45,46,47,48,49,51,56$, $60,62,63,68,71,73,74$ referred to studies conducted in the Metropolitan Region of São Paulo. Emis- sions in the cities of Rio de Janeiro 30,35,40,42,64,69, São José dos Campos (São Paulo) 50, Porto Alegre (Rio Grande do Sul) 54,56, Curitiba (Paraná) 39,56, Itabira (Minas Gerais) 55 and Vitória (Espírito Santo) 57 were also studied. In regions in the Brazilian Amazon, where air pollution is derived from biomass burning, only five studies were published between 2000 and 2009 59,61,65,66,72. Respiratory effects were also investigated in areas of sugarcane burning, especially in the state of São Paulo 24,52,53,58,67.

Hospital admissions and deaths from respiratory diseases made up the main health outcomes associated with elevated levels of air pollutants, corroborating international studies 1,2. Structural and functional alterations in lung tissue, circulatory and inflammatory mediators were investigated by experimental studies $26,37,43$, $48,51,54,63,67,68,71,73$. In the metropolitan regions of São Paulo and Rio de Janeiro, 18 ecological timeseries studies were conducted between 2000 and $200921,22,23,27,28,31,32,35,36,38,41,42,44,46,49,64,69,74$. Children, adolescents and the elderly were the main interest groups for studies that researched 
Studies on air pollution and health effects conducted in urban and biomass burning areas, according to location, study type, subject group and respiratory health outcomes published in Brazil between 2000 and 2009.

\begin{tabular}{|c|c|c|c|c|c|}
\hline References & Year & Location & Study & Subject group & Outcomes \\
\hline Gouveia \& Fletcher 21 & 2000 & São Paulo & $\begin{array}{l}\text { Ecological time-series } \\
\text { studies }\end{array}$ & $\begin{array}{l}\text { Children } \\
(<5 \text { years })\end{array}$ & Hospital admissions (RD) \\
\hline Gouveia \& Fletcher 22 & 2000 & São Paulo & $\begin{array}{l}\text { Ecological time-series } \\
\text { studies }\end{array}$ & $\begin{array}{l}\text { Children } \\
(<5 \text { years }) \\
\text { and elderly }\end{array}$ & Mortality (RD and CVD) \\
\hline Benício et al. 25 & 2000 & São Paulo & Descriptive studies & Children ( $<5$ years) & $\begin{array}{l}\text { Prevalence of diseases and respiratory } \\
\text { symptoms }\end{array}$ \\
\hline Cury et al. 26 & 2000 & São Paulo & Experimental studies & Mice & Lung injury and induction of tumors \\
\hline Martins et al. 27 & 2001 & São Paulo & $\begin{array}{c}\text { Ecological time-series } \\
\text { studies }\end{array}$ & Elderly & Emergency room visits (RD) \\
\hline Cifuentes et al. 29 & 2001 & $\begin{array}{c}\text { Santiago, São } \\
\text { Paulo, Mexico City } \\
\text { and New York }\end{array}$ & $\begin{array}{l}\text { Health impact } \\
\text { assessment }\end{array}$ & All & $\begin{array}{l}\text { Mortality and hospitalization due to RD; } \\
\text { premature deaths, chronic bronchitis } \\
\text { cases, asthma attacks and person-day } \\
\text { loss or other restricted activity }\end{array}$ \\
\hline Brilhante \& Tambellini 30 & 2002 & Rio de Janeiro & Descriptive studies & All & Emergency room visits \\
\hline Martins et al. 31 & 2002 & São Paulo & $\begin{array}{l}\text { Ecological time-series } \\
\text { studies }\end{array}$ & Elderly & Emergency room visits (RD) \\
\hline Martins et al. 32 & 2002 & São Paulo & $\begin{array}{l}\text { Ecological time-series } \\
\text { studies }\end{array}$ & Elderly & $\begin{array}{l}\text { Emergency room visits by pneumonia } \\
\text { and influenza }\end{array}$ \\
\hline Soares et al. 37 & 2003 & São Paulo & Experimental studies & Mice & $\begin{array}{l}\text { Presence of micronuclei in blood } \\
\text { erythrocytes in mice. The frequency of } \\
\text { micronuclei was dependent on the levels } \\
\text { of } \mathrm{PM}_{10}, \mathrm{NO}_{2} \text { and } \mathrm{CO}\end{array}$ \\
\hline Freitas et al. 38 & 2004 & São Paulo & $\begin{array}{l}\text { Ecological time-series } \\
\text { studies }\end{array}$ & $\begin{array}{c}\text { Children, } \\
\text { adolescent and } \\
\text { elderly }\end{array}$ & $\begin{array}{l}\text { Hospital admissions (RD) and mortality } \\
\text { (all causes) }\end{array}$ \\
\hline Bakonyi et al. 39 & 2004 & $\begin{array}{l}\text { Curitiba, Paraná } \\
\text { State }\end{array}$ & $\begin{array}{l}\text { Ecological time-series } \\
\text { studies }\end{array}$ & $\begin{array}{l}\text { Children and } \\
\text { adolescent } \\
\text { (0 to } 14 \text { years) }\end{array}$ & Outpatient visits (RD) \\
\hline Rios et al. 40 & 2004 & Rio de Janeiro & Descriptive studies & $\begin{array}{l}\text { Children and } \\
\text { adolescent } \\
\text { (13 to } 14 \text { years) }\end{array}$ & Prevalence of asthma \\
\hline Martins et al. 41 & 2004 & $\begin{array}{l}\text { Metropolitan } \\
\text { region of } \\
\text { São Paulo }\end{array}$ & $\begin{array}{l}\text { Ecological time-series } \\
\text { studies }\end{array}$ & Elderly & Mortality (RD) \\
\hline
\end{tabular}

(continues) 


\begin{tabular}{|c|c|c|c|c|c|}
\hline References & Year & Location & Study & Subject group & Outcomes \\
\hline Daumas et al. 42 & 2004 & Rio de Janeiro & $\begin{array}{l}\text { Ecological time-series } \\
\text { studies }\end{array}$ & Elderly & Mortality (RD and CVD) \\
\hline Rivero et al. 43 & 2005 & São Paulo & Experimental studies & Rats & $\begin{array}{l}\text { Cardiovascular and pulmonary alterations } \\
\text { with markers of systemic inflammation } \\
\text { after exposure to the } \mathrm{PM}_{10} \text { and } \mathrm{PM}_{2.5}\end{array}$ \\
\hline Gonçalves et al. 44 & 2005 & $\begin{array}{l}\text { Metropolitan } \\
\text { region of São } \\
\text { Paulo }\end{array}$ & $\begin{array}{l}\text { Ecological time-series } \\
\text { studies }\end{array}$ & $\begin{array}{l}\text { Children and } \\
\text { adolescent } \\
\text { (<13 years) }\end{array}$ & Hospital admissions (RD) \\
\hline Miraglia et al. 45 & 2005 & São Paulo & $\begin{array}{l}\text { Health impact } \\
\text { assessment }\end{array}$ & $\begin{array}{l}\text { Children and } \\
\text { elderly }\end{array}$ & $\begin{array}{l}\text { Burden of disease with the application } \\
\text { of DALY }\end{array}$ \\
\hline Farhat et al. 46 & 2005 & São Paulo & $\begin{array}{l}\text { Ecological time-series } \\
\text { studies }\end{array}$ & $\begin{array}{l}\text { Children and } \\
\text { adolescent } \\
\text { (<13 years) }\end{array}$ & $\begin{array}{l}\text { Emergency room visits (RD) and hospital } \\
\text { admission (RD) }\end{array}$ \\
\hline Bell et al. 47 & 2006 & $\begin{array}{l}\text { México City, } \\
\text { Santiago, São } \\
\text { Paulo }\end{array}$ & $\begin{array}{l}\text { Health impact } \\
\text { assessment }\end{array}$ & All & $\begin{array}{l}\text { Mortality, asthma attacks, emergency } \\
\text { room visits, chronic bronchitis }\end{array}$ \\
\hline Lemos et al. 48 & 2006 & São Paulo & Experimental studies & Rats & $\begin{array}{l}\text { Functional alterations of respiratory and } \\
\text { cardiac tissue }\end{array}$ \\
\hline Gouveia et al. 49 & 2006 & São Paulo & $\begin{array}{l}\text { Ecological time-series } \\
\text { studies }\end{array}$ & $\begin{array}{l}\text { Children } \\
(<5 \text { years }) \text { and } \\
\text { elderly }\end{array}$ & Hospital admission (RD and CVD) \\
\hline Nascimento et al. 50 & 2006 & $\begin{array}{l}\text { São José dos } \\
\text { Campos, São } \\
\text { Paulo State }\end{array}$ & $\begin{array}{l}\text { Ecological time-series } \\
\text { studies }\end{array}$ & $\begin{array}{l}\text { Children } \\
\text { (<10 years })\end{array}$ & Hospital admissions by pneumonia \\
\hline Camargo et al. 51 & 2006 & São Paulo & Experimental studies & Rats & $\begin{array}{l}\text { Increase in the amount of acidic mucus in } \\
\text { the respiratory epithelium of rats exposed } \\
\text { to the } \mathrm{PM}_{10} \text { and } \mathrm{NO}_{2}\end{array}$ \\
\hline Cançado et al. 52 & 2006 & $\begin{array}{l}\text { Piracicaba, São } \\
\text { Paulo State } \\
\text { (sugarcane region) }\end{array}$ & $\begin{array}{l}\text { Ecological time-series } \\
\text { studies }\end{array}$ & $\begin{array}{c}\text { Children, } \\
\text { adolescent } \\
\text { (<13 years) and } \\
\text { elderly }\end{array}$ & Hospital admissions (RD) \\
\hline Lopes \& Ribeiro 53 & 2006 & $\begin{array}{l}\text { São Paulo } \\
\text { (sugarcane region) }\end{array}$ & Descriptive studies & All & Hospital admissions (RD) \\
\hline Pereira et al. 54 & 2007 & $\begin{array}{l}\text { Porto Alegre, Rio } \\
\text { Grande do Sul } \\
\text { State }\end{array}$ & Experimental studies & Rats & $\begin{array}{l}\text { Evidence of oxidative stress and } \\
\text { mechanism responsible for acute } \\
\text { respiratory effects }\end{array}$ \\
\hline Braga et al. 55 & 2007 & $\begin{array}{l}\text { Itabira, Minas } \\
\text { Gerais State }\end{array}$ & $\begin{array}{c}\text { Ecological time-series } \\
\text { studies }\end{array}$ & $\begin{array}{l}\text { Children, elderly } \\
\text { and adults }\end{array}$ & Emergency rooms (RD and CVD) \\
\hline Solé et al. 56 & 2007 & $\begin{array}{l}\text { São Paulo, Santo } \\
\text { André, Curitiba } \\
\text { and Porto Alegre }\end{array}$ & Descriptive studies & $\begin{array}{c}\text { Adolescent } \\
\text { (13 to } 14 \text { years) }\end{array}$ & Symptoms of asthma, rhinitis and eczema \\
\hline Castro et al. 57 & 2007 & $\begin{array}{l}\text { Vitória, Espírito } \\
\text { Santo State }\end{array}$ & Descriptive studies & $\begin{array}{l}\text { Children } \\
\text { (<6 years) }\end{array}$ & $\begin{array}{l}\text { Daily records of RD, asthma and } \\
\text { pneumonia }\end{array}$ \\
\hline Arbex et al. 58 & 2007 & $\begin{array}{l}\text { São Paulo } \\
\text { (sugarcane region) }\end{array}$ & $\begin{array}{l}\text { Ecological time-series } \\
\text { studies }\end{array}$ & All & Hospital admissions (asthma) \\
\hline Ignotti et al. 59 & 2007 & $\begin{array}{l}\text { Mato Grosso } \\
\text { (Brazilian Amazon) }\end{array}$ & Descriptive studies & $\begin{array}{l}\text { Children } \\
(<5 \text { years })\end{array}$ & Hospital admissions and mortality (RD) \\
\hline Marcílio \& Gouveia 60 & 2007 & $\begin{array}{c}\text { Metropolitan } \\
\text { regions }\end{array}$ & $\begin{array}{l}\text { Health impact } \\
\text { assessment }\end{array}$ & $\begin{array}{l}\text { Children and } \\
\text { elderly }\end{array}$ & Hospital admissions and mortality (RD) \\
\hline
\end{tabular}

(continues) 


\begin{tabular}{|c|c|c|c|c|c|}
\hline References & Year & Location & Study & Subject group & Outcomes \\
\hline Duarte et al. 61 & 2007 & $\begin{array}{l}\text { Acre (Brazilian } \\
\text { Amazon) }\end{array}$ & Descriptive studies & All & Hospital admissions and mortality (RD) \\
\hline Miraglia et al. 62 & 2007 & São Paulo & $\begin{array}{l}\text { Health impact } \\
\text { assessment }\end{array}$ & All & $\begin{array}{l}\text { Hospital admissions and mortality (RD) } \\
\text { and (VD), fetal deaths }\end{array}$ \\
\hline Mauad et al 63 & 2008 & São Paulo & Experimental studies & Rats & $\begin{array}{l}\text { Reduction of volume and lung capacity in } \\
\text { rats exposed to pollution }\end{array}$ \\
\hline Moura et al. 64 & 2008 & Rio de Janeiro & $\begin{array}{c}\text { Ecological time-series } \\
\text { studies }\end{array}$ & $\begin{array}{l}\text { Children ( } 1 \text { month } \\
\text { and } 12 \text { years) }\end{array}$ & $\begin{array}{l}\text { Emergency room visits due to acute } \\
\text { respiratory symptoms }\end{array}$ \\
\hline Mascarenhas et al. 65 & 2008 & $\begin{array}{c}\text { Mato Grosso } \\
\text { (Brazilian Amazon) }\end{array}$ & Descriptive studies & All & Emergency rooms visits (RD) \\
\hline Rosa et al. 66 & 2008 & $\begin{array}{l}\text { Mato Grosso, } \\
\text { (Brazilian Amazon) }\end{array}$ & Descriptive studies & $\begin{array}{l}\text { Children and } \\
\text { adolescents } \\
\text { (<15 years) }\end{array}$ & Hospital admissions (RD) \\
\hline Mazzoli et al. 67 & 2008 & $\begin{array}{c}\text { São Paulo } \\
\text { (sugarcane } \\
\text { burning) }\end{array}$ & Experimental studies & Rats & $\begin{array}{l}\text { Intratracheal instillation of TSP from } \\
\text { sugarcane burning was associated with } \\
\text { alterations in the physiologic mechanisms } \\
\text { and lung tissue }\end{array}$ \\
\hline Maatz et al. 68 & 2009 & São Paulo & Experimental studies & Rats & $\begin{array}{c}\text { Functional heart alterations after } 2 \text { hours } \\
\text { of exposure to the } \mathrm{PM}_{2.5}\end{array}$ \\
\hline Moura et al. 69 & 2009 & Rio de Janeiro & $\begin{array}{l}\text { Ecological time-series } \\
\text { studies }\end{array}$ & $\begin{array}{l}\text { Children ( } 1 \text { month } \\
\text { and } 12 \text { years) }\end{array}$ & $\begin{array}{c}\text { Emergency room visits (symptoms or } \\
\text { airway obstruction disease) }\end{array}$ \\
\hline Castro et al. 70 & 2009 & Rio de Janeiro & Panel studies & $\begin{array}{l}\text { Children and } \\
\text { adolescents } \\
\text { (6 to15 years) }\end{array}$ & Decreased lung capacity \\
\hline $\begin{array}{l}\text { Damasceno-Rodrigues } \\
\text { et al. } 71\end{array}$ & 2009 & São Paulo & Experimental studies & Rats & $\begin{array}{l}\text { Oxidative stress in adult rats and damage } \\
\text { due to fetal exposure }\end{array}$ \\
\hline Rosa et al. 72 & 2009 & $\begin{array}{c}\text { Mato Grosso } \\
\text { (Brazilian Amazon) }\end{array}$ & Descriptive studies & $\begin{array}{l}\text { Children and } \\
\text { adolescents ( } 6 \text { to } \\
7 \text { and } 13 \text { to } \\
14 \text { years) }\end{array}$ & Prevalence of asthma \\
\hline Lopes et al. 73 & 2009 & São Paulo & Experimental studies & Rats & $\begin{array}{l}\text { Exposure to the levels of PM in urban } \\
\text { areas increases and induces outcomes } \\
\text { such as emphysema. This response may } \\
\text { be influenced by oxidative stress }\end{array}$ \\
\hline Arbex et al. 74 & 2009 & São Paulo & $\begin{array}{l}\text { Ecological time-series } \\
\text { studies }\end{array}$ & $>40$ years & Emergency rooms visits (RD-COPD) \\
\hline
\end{tabular}

COPD: chronic obstructive pulmonary disease; CVD: cardiovascular disease; DALY: disability-adjusted life years; RD: respiratory disease;

TSP: total suspended particles.

the adverse health effects of air pollution. Twenty-six studies analyzed the respiratory outcomes in children and adolescents 21,22,23,25,28,34,35,38,39, $40,44,45,46,49,50,52,55,56,57,59,60,64,66,69,70,72$ and 14 articles made reference to the elderly $22,27,31,32,33$, $35,38,41,42,45,49,52,55,60$.

Few studies were found concerning the effects of air pollution from biomass burning on human health in Brazil. In the Brazilian Amazon, the number of emergency room visits for respiratory diseases in children under the age of 10 was positively correlated with concentrations of
$\mathrm{PM}_{2.5}$ 65. Descriptive studies show a high prevalence of asthma and an increase in morbimortality due to respiratory diseases in municipalities in the subequatorial Amazon region in biomass burning areas $59,61,66,72$.

\section{Effects of pollution on the respiratory system}

Air pollution studies in Brazil were predominantly conducted in the metropolitan areas of São Paulo and Rio de Janeiro. The results of 18 time-series ecological studies were published, of which eight 
reported relative risk and $95 \%$ confidence interval $(95 \% \mathrm{CI})$ of hospital admissions and deaths due to respiratory diseases in children and the elderly associated with increments of $10 \mu \mathrm{g} / \mathrm{m}^{3}$ in the concentration of $\mathrm{PM}_{10}$ (Figure 1).

Gouveia \& Flecther 21,22 estimated $R R=1.004$ (95\%CI: 0.998-1.010) for hospital admissions due to respiratory diseases in children $(<5$ years old) and RR $=0.999$ (95\%CI: 0.967-1.031) for the number of deaths due to respiratory diseases associated with an increase of $10 \mu \mathrm{g} / \mathrm{m}^{3}$ in the concentration of $\mathrm{PM}_{10}$ in São Paulo (Figure 1a). Subsequently, in 2003 and 2006 Gouveia et al. 35,49 associated the variation of $\mathrm{PM}_{10}$ with $6.7 \%$ and $2.2 \%$ increases respectively in hospitalizations due to respiratory diseases in children (Figure 1a). In Rio de Janeiro, Gouveia et al. 35 found $\mathrm{RR}=1.018$ (95\%CI: 1.004-1.033) for hospitalizations related to respiratory diseases in children (Figure 1a).

Braga et al. 23 evaluated exposure to air pollutants and hospital admissions due to respiratory diseases in children and adolescents (0-20 years old) in São Paulo. The results showed RR = 1.026 (95\%CI: 1.022-1.029) in children under the age of 2 and $\mathrm{RR}=1.009$ (95\%CI: 1.001-1.017) in children aged 3-5, associated with increments of $10 \mu \mathrm{g} / \mathrm{m}^{3}$ with a lag period of 4 days (Figure $1 \mathrm{a}$ ). Freitas et al. 38 estimated a $1.3 \%$ increase (RR = 1.013, 95\%CI: 1.010-1.016) in hospital admissions due to respiratory diseases associated with increments of $10 \mu \mathrm{g} / \mathrm{m}^{3}$ in the concentration of $\mathrm{PM}_{10}$ (Figure 1a).

With regard to the elderly, the largest relative risk of death due to respiratory diseases was found by Martins et al. 41. Increments of 10 $\mathrm{gg} /$ $\mathrm{m}^{3}$ of daily levels of $\mathrm{PM}_{10}$ are associated with a $5.4 \%$ increase $(\mathrm{RR}=1.054,95 \% \mathrm{CI}: 1.023-1.086$ ) in mortality due to respiratory diseases in the elderly (Figure $1 \mathrm{~b}$ ). Increments of $10 \mu \mathrm{g} / \mathrm{m}^{3}$ in the daily levels of $\mathrm{PM}_{10}$ increased hospital admissions in the elderly due to respiratory diseases by $3.5 \%$ (RR $=1.035,95 \% \mathrm{CI}: 1.012-1.059)$ in Rio de Janeiro 35 (Figure 1b). In São Paulo, results calculated RR = 1.019 (95\%CI: 1.011-1.027) and $\mathrm{RR}=1.009$ (95\%CI: 1.005-1.013) respectively for hospitalization due to respiratory diseases and death due to respiratory diseases in the elderly associated with an increase of $10 \mu \mathrm{g} / \mathrm{m}^{3}$ in levels of $\mathrm{PM}_{10} 36$ (Figure $1 \mathrm{~b}$ ).

According to results from a study in São Paulo carried out by Gouveia et al, children show a higher risk of hospitalization due to respiratory diseases than the elderly, with $\mathrm{RR}=1.067$ (95\%CI:

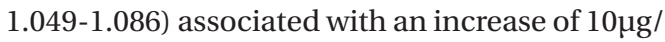
$\mathrm{m}^{3}$ in the levels of $\mathrm{PM}_{10} 35$ (Figure 1a). However, the risk of death due to respiratory diseases is higher among the elderly than in children for the same variation in $\mathrm{PM}_{10}$ levels. With respect to the elderly population over the age of 65 in São Paulo, the percentage increase in the number of deaths was $5.4 \% 41$.

\section{Discussion and conclusion}

Studies show that individuals living in biomass burning areas are exposed to short-term, high concentrations of $\mathrm{PM}_{10}$ and $\mathrm{PM}_{2.5}$ whereas individuals living in industrial regions, are chronically exposed to lower concentrations. In metropolitan areas, where peak concentrations of PM are smaller, high levels of pollutants were also found, especially during thermal inversions 15,49,70. These pollutants include fungal spores, toxins, bacterial products, pollen and endotoxins. The effects of exposure depend not only on the concentration of pollutants, but also on the time of year, duration of exposure and the toxicity of the particles to which an individual is exposed 3,4 .

In terms of adverse health effects, several respiratory problems resulting from the acute inhalation of PM were witnessed in the Southeast Region and in the Brazilian Amazon in both children and the elderly $107,108,109$. Air pollution has a direct effect on the cardiovascular system. Unfortunately however, this effect was not studied in the subequatorial Amazon region. Although, long-term exposure has been shown to be related to a lower life expectancy and increased risk of mortality from cardiopulmonary diseases in urban areas in the United States of America, this effect has still not been investigated in Brazil 2,110. In contrast, the adverse effects of short-term exposure to PM depends on the degree of toxicity of the physical and chemical characteristics of the emissions source 16. In terms of particle size, $\mathrm{PM}_{2.5}$ shows the greatest potential risk to human health resulting from inhalation, deposition and penetration deep into the pulmonary alveoli ${ }^{4}$. Deposition of fine and ultrafine particles, primarily by diffusion, in the respiratory tract increases with decreasing particle size 16 .

This physiological mechanism related to high exposure levels may explain the existence of a considerable number of cases of respiratory disease in some municipalities in the Amazon region, especially in vulnerable children and the elderly. The physical and chemical characteristics of $\mathrm{PM}_{2.5}$ receive greater attention in the literature in biomass burning areas in the Brazilian Amazon due to the link between the scientific network and the international project the Large Scale Biosphere-Atmosphere Experiment in Amazonia. Unfortunately, few studies related to the adverse health effects of $\mathrm{PM}_{2.5}$ have been carried out in this region. 
Figure 1

Studies with relative risk and $95 \%$ confidence interval for hospital admissions and death from respiratory diseases in children

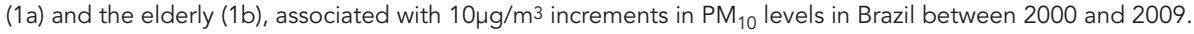

1a) Children

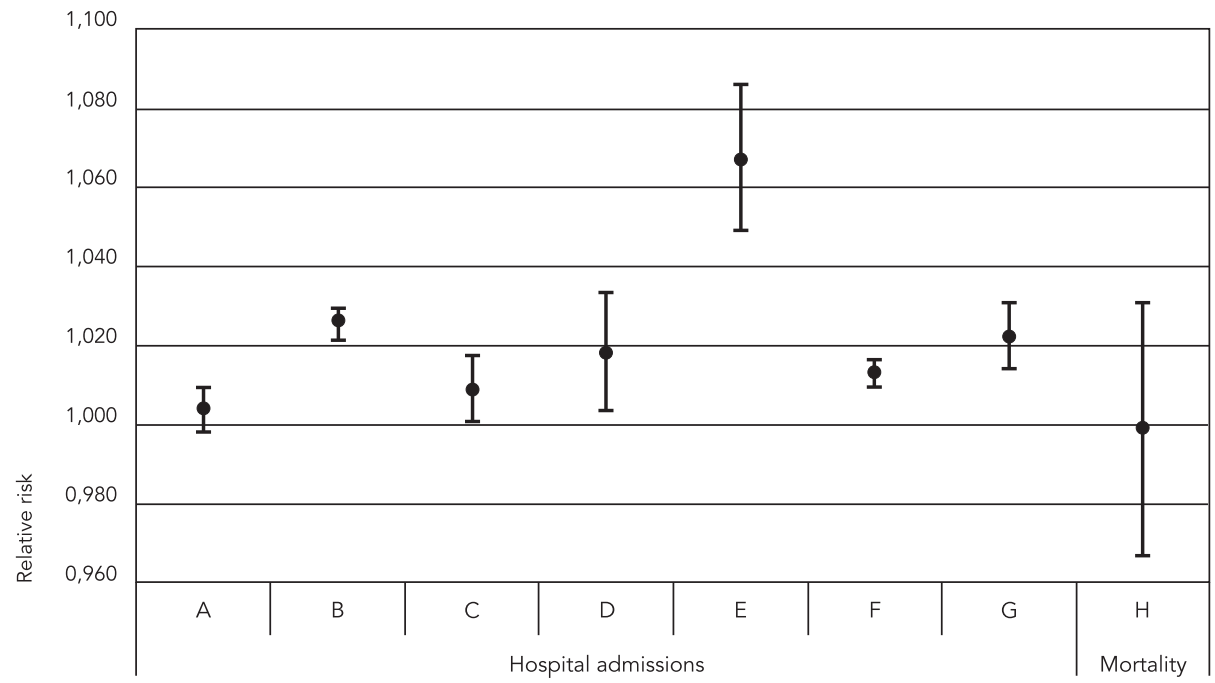

Source: Gouveia \& Fletcher 21 (A); Braga et al. 23 (B); Braga et al. 23 (C); Gouveia et al. 35 (D); Gouveia et al. 35 (E); Freitas et al. 38 (F); Gouveia et al. $49(\mathrm{G})$; Gouveia \& Fletcher $22(\mathrm{H})$

1b) Elderly

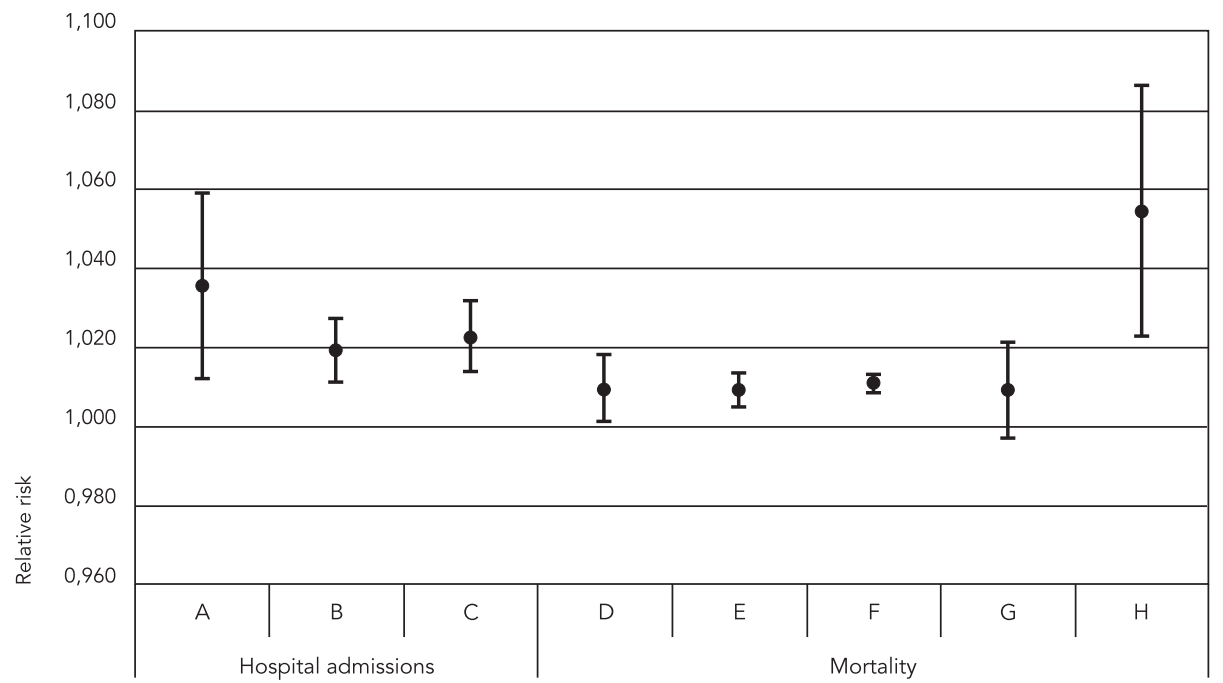

Source: Gouveia et al. 35 (A); Gouveia et al. 35 (B); Gouveia et al. 49 (C); Gouveia \& Fletcher 22 (D); Gouveia et al. 35 (E); Freitas et al. 38 (F); Daumas et al. 42 (G); Martins et al. 41 (H) 
Apart from higher concentrations of metals in urban areas, the elemental composition of PM particles released in biomass burning areas was similar to that of particles released in metropolitan areas. In the state of Minas Gerais, in the cities of Ouro Preto and Sete Lagoas, particles showed high concentrations of metals due to the presence of mining and industry sources, but these results were not related to health effects 97,111 . In a recent study by Zanobetti et al. 112, the mass of $\mathrm{PM}_{2.5}$ showed high concentrations of arsenic, nickel, chromium and bromine which were associated with increased hospital admissions in elderly residents in 26 cities in the United States.

PAHs were found in PM in metropolitan regions of Rio de Janeiro and Porto Alegre and showed genotoxic effects 8,92 . In regions where biomass burning occurs, PAHs receive little attention in the literature, but one study in the Brazilian Amazon found the presence of various hydrocarbons with potentially carcinogenic effects: fluoranthene, benzo(a)anthracene, benzo(e) pyrene indeno-(cd)pyrene, dibenzo(ah)anthracene and benzo(a)pyrene 113 .

With respect to the organic composition of PM, BC stands out as the main chemical constituent of particles released in biomass burning areas, where higher concentrations are experienced in fires areas, and urban areas. A study carried out in the Amazon biome during the 1995 dry season shows peak concentrations of $\mathrm{BC}$ in fine particulate mass at levels $\left(17.5 \mu \mathrm{g} / \mathrm{m}^{3}\right)$ that exceed annual levels of $\mathrm{PM}_{2.5}$ acceptable for human health 3,76 . BC is associated with known trace elements of emissions from burning such as $\mathrm{S}, \mathrm{K}, \mathrm{Cl}, \mathrm{Ca}$ and $\mathrm{Zn}{ }^{6}$. It has the capacity to absorb radiation and is the principle factor in the reduction of visibility caused by air pollution 114. Experimental and epidemiological studies show that exposure to ultrafine particles of BC are associated with increases in inflammatory cells, reduced alveolar macrophage activity and cardiovascular disease 115,116.

For all emission sources, $\mathrm{SO}_{4}{ }^{2-}$ was the most highly concentrated element of all the inorganic components of $\mathrm{PM}_{2.5}$. This formation of sulfates involves the conversion of $\mathrm{SO}_{2}$ to sulfuric acid $\left(\mathrm{H}_{2} \mathrm{SO}_{4}\right)$ 117. Experimental studies show that acute exposure to $\mathrm{H}_{2} \mathrm{SO}_{4}$ produces inflammatory responses in humans and animals 3,4,118 and its corrosive characteristics may influence $\mathrm{PM}_{2.5}$ lung deposition and lung compartment clearance rates 117 .

Eventually, at low temperatures, $\mathrm{H}_{2} \mathrm{SO}_{4}$ is neutralized by the presence of ammonia $\left(\mathrm{NH}_{4}\right)$. Thus, in areas in the Amazon region, lower $\mathrm{NH}_{4}$ deposition rates during the dry season could lead to increases in the availability of $\mathrm{H}_{2} \mathrm{SO}_{4}$ in fine fractions of $\mathrm{PM}_{2.5}$, so increasing adverse health effects 88 . However, in urban areas, due to the number of motor vehicles, emissions of $\mathrm{SO}_{2}$ are higher than in biomass burning areas, contributing to the formation of $\mathrm{H}_{2} \mathrm{SO}_{4}$.

Studies project an annual growth rate of 3.5\% in sales of smaller vehicles through to 2015 and of $2.2 \%$ as from 2016, leading to increases of $\mathrm{SO}_{2}$, $\mathrm{NO}_{2}$ and PM emissions 119. The studies that detected a link between daily changes in PM and daily mortality generally showed that the effects were greater in the elderly and among individuals with selected underlying diseases. Several epidemiological studies have associated daily levels of these pollutants with cardiopulmonary effects 49,55,70. Research on exposure to multipollutants has been widely conducted with respect to PM and the adverse health effects associated with constituents of particulate mass 5,67,112. However, adverse effects from simultaneous exposure to all these pollutants have gained little attention in Brazil.

Several time-series studies were conducted in metropolitan areas to investigate the health effects of air pollution 21,22,23,27,28,31,32,35,36,38,41,42, 44,46,49,64,69,74. Published in 2007, the first studies on the health effects of air pollution in biomass burning areas in the Brazilian Amazon were limited to descriptive studies and focused mainly on asthma 59,61,65,66,72. Time-series studies conducted in the subequatorial Amazon showed that daily levels of $\mathrm{PM}_{2.5}$ measured during the peak of the dry season led to an increase in the percentage of hospital admissions and outpatient visits due to respiratory diseases in children and the elderly 107,109. These results corroborate with those observed in the Southeast Region of Brazil in areas where sugarcane burning occurs 52 .

Time-series studies are essential to investigate the acute health effects of air pollution. However, certain limitations of study design make it difficult to estimate uncertainties surrounding environmental factors, exposure and outcome. Individual details are not included in the analysis and it is possible that some outcomes may include the effects of exposure to other pollutants and factors 36,120 . Longitudinal and experimental studies with a more detailed analysis of exposure and outcome at the individual level and multiple air pollutants could reduce uncertainties related to the effects of atmospheric particulates on health.

Children, one of the groups that are most sensitive to the effects of air pollution, showed greater susceptibility to respiratory problems due to variation in PM levels. This is due in part to the influence of children's anatomical and physiological characteristics on the deposition and 
removal of inhaled particles 121 . Moreover, immunological immaturity interferes with recovery from damage caused by pollution 122 .

The fractions of PM deposited in the tracheobronchial region can be removed during the first 24-48 hours by mucociliary activity 123 , whilst the particles that reach the alveolar regions are only cleared, preferably by the action of macrophages or by alternative mechanisms, after a period of weeks or even months 124. Therefore, individuals exposed to higher concentrations of PM living in areas where biomass burning lasts on average for only three months of the year (in the Brazilian Amazon for example) may experience better physiological recovery than those individuals in urban areas who are subject to constant exposure.

This overview of Brazilian anthropogenic sources of exposure to air pollution is dependent on the availability and quality of information found in scientific databases in the public domain. The differences in methodologies used by these studies to measure exposure and the physical and chemical characteristics of anthropogenic sources of air pollutants may limit the comparison of results. However, based on the concordance between results, considerations may be made on the physical and chemical characteristics of the pollutants and the adverse effects of air pollution on health. It should be noted that this is a systematic overview and not an exhaustive review of current data. Only selected areas related to human health have been discussed.
This systematic review suggests that the exposure-response relationship between daily changes in PM aerosol and daily outcomes differs between Brazilian biomass burning areas and metropolitan areas in terms of time, duration and toxicity of particles. In general, the data consistently shows that the current Brazilian air pollution standards 125 are not protecting human health from exposure to air pollution in metropolitan and biomass burning areas . Clearly, these standards may be considered "unhealthy", suggesting that the Brazilian government and private sector need to discuss and establish specific standards and regulations for $\mathrm{PM}_{2.5}$. The São Paulo government is currently considering standards, however, national legislation to address the protection of human health on a countrywide basis is necessary.

In conclusion, the results of these studies on the effects of air pollution on health are specific to the study area and may not be applicable to areas with different anthropogenic emission sources. In Brazil, children are the group that is most sensitive to hospitalizations and deaths due to respiratory diseases followed by the elderly. However, there is a need for further study of the health effects of PM in the Brazilian Amazon. Although epidemiological studies have demonstrated a relationship between PM aerosol and its detrimental effects on health, these associations are fraught with uncertainties due to methodological limitations and the synergistic effects of environmental factors and pollutants and the physical ramifications of $\mathrm{PM}$. 


\section{Resumo}

O objetivo deste estudo foi revisar as publicações científicas em relação às características dos poluentes atmosféricos, especialmente material particulado (PM), e os efeitos respiratórios na saúde, segundo diferentes fontes de emissões, no período de 2000 a 2009, no Brasil. Revisão sistemática da literatura realizada em bases de dados eletrônicas. Foram analisadas publicações relacionadas às características físico-químicas dos poluentes, segundo diferentes fontes de emissões $e$ estudos relativos aos efeitos no sistema respiratório. $O$ PM é composto predominantemente de compostos orgânicos e $20 \%$ de elementos inorgânicos. Altas concentrações de metais foram identificadas em áreas metropolitanas quando comparadas às regiões de queimadas. O risco relativo de internações hospitalares por doenças respiratórias em crianças foi superior àqueles encontrados em idosos. Os resultados dos estudos sobre os efeitos da poluição do ar na saúde não devem ser transferidos para áreas com diferentes fontes de emissão.

Poluentes Ambientais; Poluentes do Ar; Material Particulado; Doenças Respiratórias

\section{Contributors}

B. F. A. Oliveira contributed to the analysis of the bibliographical references from the database search, structuring and drafting of the article and discussions on preparing the article. E. Ignotti and S. S. Hacon collaborated in the review and selection of the publications, and in the revision of the article.

\section{Acknowledgements}

We are grateful to: W. L. Junger for useful insights into relative risk estimates; N. Gouveia for information provided on the standard error and coefficient $(\beta)$ in his studies; Elaine Rua Rodriguez Rochedo for her valuable contributions.

\section{References}

1. Atkinson RW, Anderson HR, Sunyer J, Ayres J, Baccini M, Vonk JM, et al. Acute effects of particulate air pollution on respiratory admissions: results from APHEA 2 project. Air Pollution and Health: a European Approach. Am J Respir Crit Care Med 2001; 164:1860-6.

2. Pope CA, Burnett RT, Thun MJ, Calle EE, Krewski $\mathrm{D}$, Ito $\mathrm{K}$, et al. Lung cancer, cardiopulmonary mortality, and long-term exposure to fine particulate air pollution. JAMA 2002; 287:1132-41.

3. World Health Organization. Global air quality guidelines. Report on a Working Group Meeting, Bonn, Germany, October 18-20, 2005. Copenhagen: World Health Organization, Regional Office for Europe; 2005.
4. U.S. Environmental Protection Agency. Air quality criteria for particulate matter. Research Triangle Park: National Center for Environmental Assessment-RTP Office; 2004.

5. Dominici F, Roger DP, Christopher DB, Bell LM. Protecting human health from air pollution: shifting from a single-pollutant to a multipollutant approach. Epidemiology 2010; 21:187-94.

6. Artaxo P, Fernandes ET, Martins JV, Yamasoe MA, Hobbs P, Maenhaut W, et al. Large-scale aerosol source apportionment in Amazonia. Journal of Geophysical Research 1998; 103:31837-47.

7. Castanho DA, Artaxo P. Wintertime and summertime São Paulo aerosol source apportionment study. Atmos Environ 2001; 35:4889-902. 
8. Gioda A, Sales JA, Cavalcanti PMS, Maia MF, Maia LFPG, Aquino Neto FR. Evaluation of air quality in Volta Redonda, the main metallurgical industrial city in Brazil. J Braz Chem Soc 2004; 14:856-64.

9. Fearnside PM. Desmatamento na Amazônia brasileira: história, índices e conseqüências. Megadiversidade 2005 ; 1:113-23.

10. Moosmüller HS, Collett Jr. JL, Hao WM, Kreidenweis SM, Malm WC. Characterization of particle emissions from laboratory combustion of wildland fuels. Newsletter of the Integrated Land Ecosystem-Atmosphere Processes Study 2007; 4:22-3.

11. Freitas SR, Longo KM, Silva-Dias MAF, Silva-Dias PL. Emissões de queimadas em ecossistemas da América do Sul. Estud Av 2005; 19:167-85.

12. Maenhaut W, Fernández-Jiménez MT, Rajta I, Artaxo P. Two-year study of atmospheric aerosols in Alta Floresta, Brazil: multielemental composition and source apportionment. Nucl Instrum Methods Phys Res B 2002; 189:243-8.

13. Guyon P, Graham B, Roberts GC, Mayol-Bracero OL, Maenhaut W, Artaxo P, et al. Sources of optically active aerosol particles over the Amazon forest. Atmos Environ 2004; 38:39-51.

14. Arbex M, Cançado J, Pereira L, Braga A, Saldiva P. Queima de biomassa e efeitos sobre a saúde. J Bras Pneumol 2004; 30:158-75.

15. Companhia de Tecnologia de Saneamento Ambiental. Relatório de qualidade do ar no estado de São Paulo 2008. http://www.cetesb.sp.gov.br/Ar/ publicacoes.asp (acessado em 10/Mar/2010).

16. Kim CS, Jaques P. Respiratory dose of inhaled ultrafine particles in healthy adults. Philos Trans $\mathrm{R}$ Soc London A 2000; 358:2693-705.

17. Duchiade MP. Air pollution and respiratory diseases: a review. Cad Saúde Pública 1992; 8:311-30.

18. André PA, Braga ALF, Lin CA, Conceição GMS, Pereira LAAP, Miraglia SGEK, et al. Environmental epidemiology applied to urban atmospheric pollution: a contribution from the Experimental Air Pollution Laboratory (LPAE). Cad Saúde Pública 2000; 16:619-28.

19. Pan American Health Organization. An assessment of health effects of ambient air pollution in Latin America and the Caribbean. Washington DC: Pan American Health Organization; 2005.

20. Cançado J, Braga A, Pereira LAA, Arbex MA, Saldiva PHN, Santos UP, et al. Repercussões clínicas da exposição à poluição atmosférica. J Bras Pneumol 2006; 32:S5-11.

21. Gouveia N, Fletcher T. Respiratory disease in children and outdoor air pollution in São Paulo, Brazil: a time-series analysis. Occup Environ Med 2000; 57:477-83.

22. Gouveia N, Fletcher T. Time-series analysis of air pollution and mortality: effects by cause, age and socioeconomic status. J Epidemiol Community Health 2000; 54:750-5.

23. Braga AL, Saldiva PHN, Pereira LAA, Menezes JJC, Conceição GMS, Lin CAL, et al. Health effects of air pollution exposure on children and adolescents in Sao Paulo, Brazil. Pediatr Pulmonol 2001; 31:106-13.
24. Arbex MA, Bohm GM, Saldiva PH, Conceição GM, Pope AC, Braga AL. Assessment of the effects of sugarcane plantation burning on daily counts of inhalation therapy. J Air Waste Manag Assoc 2000; 50:1745-96.

25. Benicio MHD, Cardoso MRA, Gouveia NC, Monteiro CA. Tendência secular da doença respiratória na infância na cidade de São Paulo (1984-1996). Rev Saúde Pública 2000; 34:91-101.

26. Cury PM, Lichtenfels AJ, Reymão MS, Conceição GM, Capelozzi VL, Saldiva PH. Urban levels of air pollution modifies the progression of urethaneinduced lung tumours in mice. Pathol Res Pract 2000; 196:627-33.

27. Martins LC, Latorre MRDO, Saldiva PHN, Braga ALF. Relação entre poluição atmosférica e atendimentos por infecção das vias aéreas superiores no município de São Paulo: avaliação do rodízio de veículos. Rev Bras Epidemiol 2001; 4:220-9.

28. Conceição GMS, Miraglia SGEK, Kishi HS, Saldiva PHN, Singer JM. Air pollution and child mortality: a time-series study in São Paulo, Brazil. Environ Health Perspect 2001; 109:347-50.

29. Cifuentes L, Borja-Aburto VH, Gouveia N, Thurston G, Davis DL. Assessing the health benefits of urban air pollution reductions associated with climate change mitigation (2000-2020): Santiago, São Paulo, Mexico City, and New York City. Environ Health Perspect 2001; 109:419-25.

30. Brilhante OM, Tambellini AMT. Particulate suspended matters and cases of respiratory diseases in Rio de Janeiro city (Brazil). Int J Environ Health Res 2002; 12:169-74.

31. Martins LC, Latorre MRDO, Saldiva PH, Braga AL. Air pollution and emergency room visits due to chronic lower respiratory disease in the elderly: an ecological times-series study in São Paulo, Brazil. J Occup Environ Med 2002; 44:622-7.

32. Martins LC, Latorre MRDO, Cardoso MR, Gonçalves FL, Saldiva PH, Braga AL. Air pollution and emergency room visits due to pneumonia and influenza in São Paulo, Brazil. Rev Saúde Pública 2002; 36:88-94.

33. Botter DA, Jorgensen B, Peres AA. A longitudinal study of mortality and air pollution for São Paulo, Brazil. J Expo Anal Environ Epidemiol 2002; 12:335-43.

34. Ribeiro H, Cardoso MR. Air pollution and children's health in São Paulo (1986-1998). Soc Sci Med 2003; 57:2013-22.

35. Gouveia N, Mendonça GAS, Ponce de Leon A, Correia JEM, Junger WL, Freitas CU, et al. Poluição do ar e efeitos na saúde nas populações de duas grandes metrópoles brasileiras. Epidemiol Serv Saúde 2003; 12:29-40.

36. Gouveia N, Hajat S, Armstrong B. Socioeconomic differentials in the temperature-mortality relationship in São Paulo, Brazil. Int J Epidemiol 2003; 32:390-7.

37. Soares SR, Bueno-Guimarães HM, Ferreira CM, Rivero DH, De Castro I, Garcia ML. Urban air pollution induces micronuclei in peripheral erythrocytes of mice in vivo. Environ Res 2003; 92:191-6. 
38. Freitas C, Bremner AS, Gouveia N, Pereira LA, Saldiva PH. Internações e óbitos e sua relação com a poluição atmosférica em São Paulo, 1993 a 1997. Rev Saúde Pública 2004, 38:751-7.

39. Bakonyi SMC, Danni-Oliveira IM, Martins LC, Braga ALF. Air pollution and respiratory diseases among children in the city of Curitiba, Brazil. Rev Saúde Pública 2004; 38:695-700.

40. Rios JL, Boechat JL, Sant'Anna CC, França AT. Atmospheric pollution and the prevalence of asthma: study among schoolchildren of 2 areas in Rio de Janeiro, Brazil. Ann Allergy Asthma Immunol 2004; 92:629-34.

41. Martins MCH, Fatigati FL, Véspoli TC, Martins LC, Pereira LAA, Martins MA, et al. Influence of socioeconomic conditions on air pollution adverse health effects in elderly people: an analysis of six regions in São Paulo, Brazil. J Epidemiol Community Health 2004; 58:41-6.

42. Daumas RP, Mendonça GAS, Ponce de Léon A. Poluição do ar e mortalidade em idosos no Município do Rio de Janeiro: análise de série temporal. Cad Saúde Pública 2004; 20:311-9.

43. Rivero DH, Soares SR, Lorenzi-Filho G, Saiki M, Godleski JJ, Antonangelo L, et al. Acute cardiopulmonary alterations induced by fine particulate matter of São Paulo, Brazil. Toxicol Sci 2005; 85:898-905.

44. Gonçalves FL, Carvalho LM, Conde FC, Latorre MR, Saldiva PH, Braga AL. The effects of air pollution and meteorological parameters on respiratory morbidity during the summer in São Paulo city. Environ Int 2005; 31:343-9.

45. Miraglia SGEK, Saldiva PHN, Böhm GM. An evaluation of air pollution health impacts and costs in São Paulo, Brazil. Environ Manage 2005; 35:667-76.

46. Farhat SCL, Paulo RLP, Shimoda TM, Conceição GMS, Lin CA, Braga ALF, et al. Effect of air pollution on pediatric respiratory emergency room visits and hospital admissions. Braz J Med Biol Res 2005; 38:227-35.

47. Bell ML, Davis DL, Gouveia N, Borja-Arbuto VH, Cifuentes LA. The avoidable health effects of air pollution in three Latin American cities: Santiago, São Paulo, and Mexico City. Environ Res 2006; 100:431-40.

48. Lemos M, Mohallen SV, Macchione M, Dolhnikoff M, Assunção JV, Godleski JJ, et al. Chronic exposure to urban air pollution induces structural alterations in murine pulmonary and coronary arteries. Inhal Toxicol 2006; 18:247-53.

49. Gouveia N, Freitas CU, Martins LC, Marcilio IO. Hospitalizações por causas respiratórias e cardiovasculares associadas à contaminação atmosférica no Município de São Paulo, Brasil. Cad Saúde Pública 2006 ; 22:2669-77.

50. Nascimento LF, Pereira LAA, Braga ALF, Módolo MCC, Carvalho Jr. JA. Efeitos da poluição atmosférica na saúde infantil em São José dos Campos, SP. Rev Saúde Pública 2006; 40:77-82.

51. Pires-Neto RC, Lichtenfels AJ, Soares SR, Macchione M, Saldiva PHN, Dolhnikoff M. Effects of São Paulo air pollution on the upper airways of mice. Environ Res 2006; 101:356-61.
52. Cançado JED, Saldiva PHN, Pereira LAA, Lara LBLS, Artaxo P, Martinelli LA, et al. The impact of sugarcane-burning emissions on the respiratory system of children and the elderly. Environ Health Perspect 2006; 114:725-9.

53. Lopes FS, Ribeiro H. Mapeamento de internações hospitalares por problemas respiratórios e possíveis associações à exposição humana aos produtos da queima de palha de cana-de-açúcar no estado de São Paulo. Rev Bras Epidemiol 2006; 9:215-25.

54. Pereira CE, Heck TG, Saldiva PH, Rhoden CR. Ambient particulate air pollution from vehicles promotes lipid peroxidation and inflammatory responses in rat lung. Braz J Med Biol Res 2007; 40:1353-9.

55. Braga ALF, Pereira LAA, Procópio M, André PA, Saldiva PHN. Associação entre poluição atmosférica e doenças respiratórias e cardiovasculares na cidade de Itabira, Minas Gerais, Brasil. Cad Saúde Pública 2007; 23 Suppl 4:S570-8.

56. Solé D, Camelo-Nunes IC, Wandalsen GF, Pastorino AC, Jacob CMA, Gonzalez C. Prevalence of symptoms of asthma, rhinitis, and atopic eczema in Brazilian adolescents related to exposure to gaseous air pollutants and socioeconomic status. J Investig Allergol Clin Immunol 2007; 17:6-13.

57. Castro HA, Hacon S, Argento R, Junger WL, Mello $\mathrm{CF}$, Castiglioni Júnior N, et al. Air pollution and respiratory diseases in the Municipality of Vitória, Espírito Santo State, Brazil. Cad Saúde Pública 2007; 23 Suppl 4:S630-42.

58. Arbex MA, Martins LC, Oliveira RC, Pereira LA, Arbex FF, Cançado JE, et al. Air pollution from biomass burning and asthma hospital admissions in a sugarcane plantation area in Brazil. J Epidemiol Community Health 2007; 61:395-400.

59. Ignotti E, Hacon SS, Silva AMC, Junger WL, Castro HA. Efeitos das queimadas na Amazônia: método de seleção dos municípios segundo indicadores de saúde. Rev Bras Epidemiol 2007; 10:453-64.

60. Marcilio I, Gouveia N. Quantifying the impact of air pollution on the urban population of Brazil. Cad Saúde Pública 2007; 23 Suppl 4:S529-36.

61. Duarte AF, Rabelo Júnior J, Santos GM. Influencia de la polución del aire sobre la salud en Rio Branco-AC, Brasil. Rev Cub Salud Pública 2007; 33(4). http://www.scielosp.org/scielo.php?script=sci arttext\&pid=S0864-34662007000400006\&lng=en.

62. Miraglia SGEK. Health, environmental, and economic costs from the use of a stabilized diesel/ ethanol mixture in the city of São Paulo, Brazil. Cad Saúde Pública 2007; 23 Suppl 4:S559-69.

63. Mauad T, Rivero DH, Oliveira RC, Lichtenfels AJ, Guimarães ET, Andre PA, et al. Chronic exposure to ambient levels of urban particles affects mouse lung development. Am J Respir Crit Care Med 2008; 178:721-8.

64. Moura M, Junger WL, Mendonça GAS, Ponce de Leon A. Qualidade do ar e transtornos respiratórios agudos em crianças. Rev Saúde Pública 2008; 42:503-11. 
65. Mascarenhas MDM, Vieira LC, Lanzieri TM, Leal APPR, Duarte AF, Hatch DL. Poluição atmosférica devida à queima de biomassa florestal e atendimentos de emergência por doença respiratória em Rio Branco, Brasil-Setembro, 2005. J Bras Pneumol 2008; 34:42-6.

66. Rosa MR, Ignotti E, Hacon SS, Castro H. Análise das internações por doenças respiratórias em Tangará da Serra - Amazônia Brasileira. J Bras Pneumol 2008; 34:575-82.

67. Mazzoli-Rocha F, Magalhães CB, Malm O, Saldiva PH, Zin WA, Faffe DS. Comparative respiratory toxicity of particles produced by traffic and sugarcane burning. Environ Res 2008; 108:35-41.

68. Maatz LF, Wood GJA, Rivero DHRF, Saldiva PHN. Tracheal instillation of urban PM2,5 suspension promotes acute cardiac polarization changes in rats. Braz J Med Biol Res 2009; 42:207-13.

69. Moura M, Junger WL, Mendonça GAS, Ponce de Leon A. Air quality and emergency pediatric care for symptoms of bronchial obstruction categorized by age bracket in Rio de Janeiro, Brazil. Cad Saúde Pública 2009; 25:635-44.

70. Castro HAD, Cunha MFD, Mendonça GAS, Junger WL, Cunha-Cruz J, Ponce de Leon A. Effect of air pollution on lung function in schoolchildren in Rio de Janeiro, Brazil. Rev Saúde Pública 2009; 43:26-34.

71. Damaceno-Rodrigues NR, Veras MM, Negri EM, Zanchi ACT, Rhoden CR, Saldiva PHN, et al. Effect of pre and postnatal exposure to urban air pollution on myocardial lipid peroxidation levels in adult mice. Inhal Toxicol 2009; 21:1129-37.

72. Rosa AM, Ignotti E, Hacon SDS, Castro HAD. Prevalence of asthma in children and adolescents in a city in the Brazilian Amazon region. J Bras Pneumol 2009; 35:7-13.

73. Lopes FD, Pinto TS, Arantes-Costa FM, Mriya HT, Biselli PJ, Ferraz LF, et al. Exposure to ambient levels of particles emitted by traffic worsens emphysema in mice. Environ Res 2009; 109:544-51.

74. Arbex MA, Souza Conceição GM, Cendon SP, Arbex FF, Lopes AC, Moysés EP, et al. Urban air pollution and chronic obstructive pulmonary diseaserelated emergency department visits. J Epidemiol Community Health 2009; 63:777-83.

75. Yamasoe MA, Artaxo P, Miguel AH, Allen AG. Chemical composition of aerosol particles from direct emissions of vegetation fires in the Amazon Basin: water-soluble species and trace elements. Atmos Environ 2000; 34:1641-53.

76. Artaxo P, Campos RC, Fernandes ET, Martins JV, Xiao Z, Lindqvist $\mathrm{O}$, et al. Large scale mercury and trace element measurements in the Amazon basin. Atmos Environ 2000; 34:4085-96.

77. Artaxo P, Martins JV, Yamasoe MA, Procópio AS, Pauliquevis TM, Andreae MO, et al. Physical and chemical characteristics of aerosols in the wet and dry season in Rondônia, Amazonia. Journal of Geophysical Research 2002; 107:49.1-49.14.
78. Mayol-Bracero OL, Guyon P, Graham B, Roberts G, Andreae MO, Decesari S, et al. Water-soluble organic compounds in biomass burning aerosols over Amazonia: 2. Apportionment of the chemical composition and importance of the polyacidic fraction. Journal of Geophysical Research 2002; 107:8091-106

79. Graham B, Guyon P, Taylor PE, Artaxo P, Maenhaut W, Glovsky MM, et al. Organic compounds present in the natural Amazonian aerosol: characterization by gas chromatography-mass spectrometry. Journal of Geophysical Research 2003; 108:4766-

80. Allen AG, Cardoso AA, Rocha GO. Influence of sugarcane burning on aerosol soluble ion composition in Southeastern Brazil. Atmos Environ 2004; 38:5025-38.

81. Trebs I, Metzger S, Meixner FX, Helas GN, Hoffer A, Rudich Y, et al. The NH4+-NO3--Cl--SO42--H2O aerosol system and its gas phase precursors at a pasture site in the Amazon Basin: How relevant are mineral cations and soluble organic acids? Journal of Geophysical Research 2005; 110:D07303.

82. Artaxo P, Gatti LV, Leal AMC, Longo KM, Freitas SR, Lara LL, et al. Química atmosférica na Amazônia: a floresta e as emissões de queimadas controlando a composição da atmosfera amazônica. Acta Amaz 2005; 35:85-96.

83. Mahowald NM, Artaxo P, Baker AR, Jickells TD, Okin GS, Randerson J, et al. Impacts of biomass burning emissions and land use change on Amazonian atmospheric phosphorus cycling and deposition. Global Biogeochem Cycles 2005; 19:GB4030.

84. Lara LL, Artaxo P, Martinelli LA, Victoria RL, Ferraz ESB. Characteristics of aerosols from sugar-cane burning emissions in Southeastern Brazil. Atmos Environ 2005; 39:4627-36.

85. Chand D, Guyon P, Artaxo P, Schmid O, Frank GP, Rizzo LV, et al. Optical and physical characteristics of aerosols in the boundary layer and free troposphere over the Amazon Basin during the biomass burning season. Atmos Chem Phys 2006; 6:2911-25.

86. Fuzzi S, Decesari S, Facchini MC, Cavalli F, Emblico L, Mircea M, et al. Overview of the inorganic and organic composition of size-segregated aerosol in Rondônia, Brazil, from the biomass-burning period to the onset of the wet season. Journal of Geophysical Research 2007; 112:D01201.

87. Pauliquevis T, Lara LL, Antunes ML, Artaxo P. Aerosol and precipitation chemistry in a remote site in Central Amazonia: the role of biogenic contribution. Atmos Chem Phys Discuss 2007; 7:11465-509.

88. Bertran CA, Marques CST. Study of the particulate matter emitted from residual oil combustion and natural gas reburning. J Braz Chem Soc 2004; 15:548-55.

89. Braga CF, Teixeira EC, Alves RCM. Estudo de aerossóis atmosféricos e aplicação de modelos numéricos. Quim Nova 2004; 27:567-73.

90. Quitério SL, Arbilla G, Silva CRS, Escaleira V. Metals in airborne particulate matter in the Industrial District of Santa Cruz, Rio de Janeiro, in an annual period. Atmos Environ 2004; 38:321-31. 
91. Miranda RM, Andrade MF, Fattori PA. Preliminary studies of the effect of aerosols on nitrogen dioxide photolysis rates in the city of São Paulo, Brazil. Atmos Res 2005; 75:135-48.

92. Dallarosa JB, Mônego JG, Teixeira EC, Stefens JL, Wiegand F. Polycyclic aromatic hydrocarbons in atmospheric particles in the metropolitan area of Porto Alegre, Brazil. Atmos Environ 2005; 39: 1609-25.

93. Braga CF, Teixeira EC, Meira L, Wiegand F, Yoneama ML, Dias JF. Elemental composition of PM10 and PM2,5 in urban environment in South Brazil. Atmos Environ 2005; 39:1801-15.

94. Carvalho-Oliveira A, Pozo RMK, Lobo DJA, Lichtenfels AJFC, Martins-Júnior HA, Bustilho JOW, et al. Diesel emissions significantly influence composition and mutagenicity of ambient particles: a case study in São Paulo, Brazil. Environ Res 2005; 98:1-7.

95. Miranda RM, Andrade MF. Physicochemical characteristics of atmospheric aerosol during winter in the São Paulo Metropolitan area in Brazil. Atmos Environ 2005; 39:6188-93.

96. Pereira PAP, Lopes WA, Carvalho LS, Rocha GO, Bahia NC, Loyola J, et al. Atmospheric concentrations and dry deposition fluxes of particulate trace metals in Salvador, Bahia, Brazil. Atmos Environ 2007; 41:7837-59.

97. Queiroz PGM, Jacomino VMF, Menezes MABC. Composição elementar do material particulado presente no aerossol atmosférico do município de Sete Lagoas, Minas Gerais. Quim Nova 2007; 30:1233-9.

98. Bourotte C, Curi-Amarante AP, Forti MC, Pereira LAA, Braga AL, Lotufo PA. Association between ionic composition of fine and coarse aerosol soluble fraction and peak expiratory flow of asthmatic patients in São Paulo city (Brazil). Atmos Environ 2007; 41:2036-48

99. Silva LID, Sarkis JES, Zotin FMZ, Carneiro MC, Alcover Neto A, Silva ASAG, et al. Traffic and catalytic convert - related atmospheric contamination in the metropolitan region of the city of Rio de Janeiro, Brazil. Chemosphere 2008; 71:677-84.

100. Miranda R, Tomaz E. Characterization of urban aerosol in Campinas, São Paulo, Brazil. Atmos Res 2008; 87:147-57.

101. Godói RHM, Braga DM, Makarovska Y, Alfoldy B, Carvalho Filho MAS, Grieken RV, et al. Inhable particulate matter from lime industries: Chemical composition and deposition in human respiratory tract. Atmos Environ 2008; 42:7027-33.

102. Toledo VE, Almeida Júnior PB, Quiterio SL, Arbilla G, Moreira A, Escaleira V, et al. Evaluation of levels, sources and distribution of toxic elements in PM10 in a suburban industrial region Rio de Janeiro, Brazil. Environ Monit Assess 2008; 139: 49-59.

103. Godoy MLDP, Godoy JM, Roldão LA, Soluri DS, Donagemma RA. Coarse and fine aerosol source apportionment in Rio de Janeiro, Brazil. Atmos Environ 2009; 43:2366-74.

104. Teixeira EC, Meire L, Santana ERR, Wiegand F. Chemical composition of PM10 and PM2,5 and seasonal variation in South Brazil. Water Air Soil Pollut 2009; 199:261-75.
105. Sánchez-Ccoyllo OR, Ynoue RY, Martins LD, Astolfo R, Miranda RM, Freitas ED. Vehicular particulate matter emissions in road tunnels in São Paulo, Brazil. Environ Monit Assess 2009; 149:241-9.

106. Jacomino VMF, Barreto AA, Tavares FVF, Peixoto $\mathrm{CM}$, Rodrigues PCH. Avaliação da qualidade do are $\mathrm{m}$ um polo produtor de ferro-gusa. Eng Sanit Ambient 2009; 14:511-20.

107. do Carmo CN, Hacon S, Longo KM, Freitas S, Ignotti E, de Leon AP, et al. Association between particulate matter from biomass burning and respiratory diseases in the southern region of the Brazilian Amazon. Rev Panam Salud Pública 2010; 27:10-6.

108. Ignotti E, Valente JG, Longo KM, Freitas SR, Hacon SDS, Netto PA. Impact on human health of particulate matter emitted from burning in the Brazilian Amazon region. Rev Saúde Pública 2010; 44:121-30.

109. Ignotti E, Hacon SDS, Junger WL, Mourão D, Longo K, Freitas S, et al. Air pollution and hospital admissions for respiratory diseases in the subequatorial Amazon: a time-series approach. Cad Saúde Pública 2010; 26:747-61.

110. Pope CA, Ezzati M, Dockery D. Fine-particulate air pollution and life expectancy in the United States. N Engl J Med 2009; 360:376-86.

111. Magalhães LC, Nalini Junior HA, Lima AC, Coutrim MX. Determinação de metais traço no material particulado em suspensão em Ouro Preto, Minas Gerais. Quim Nova 2010; 33:519-23.

112. Zanobetti A, Franklin M, Koutrakis P, Schwartz J. Fine particulate air pollution and its components in association with cause-specific emergency admissions. Environ Health 2009; 8:58.

113. Vasconcellos PC, Artaxo PE, Ciccioli P, Cecinato A, Brancaleoni E, Frattoni M. Determinação dos hidrocarbonetos saturados e policíclicos aromáticos presentes no material particulado da atmosfera Amazônica. Quim Nova 1998; 21:385-93.

114. Andreae MO, Gelencsér A. Black carbon or brown carbon? The nature of light-absorbing carbonaceous aerosols. Atmos Chem Phys 2006; 6: 3131-48.

115. Renwick LC, Brown D, Clouter A, Donalson $\mathrm{K}$. Increased inflammation and altered macrophage chemotactic responses caused by two ultrafine particle types. Occup Environ Med 2004; 61:442-7.

116. Gilmour PS, Ziesenis A, Morrison ER, Vickers MA, Drost EM, Ford I, et al. Pulmonary and systemic effects of short-term inhalation exposure to ultrafine carbon black particles. Toxicol Appl Pharmacol 2004; 195:35-44.

117. Schlesinger RB. The health impact of common inorganic components of fine particulate matter (PM2,5) in ambient air: a critical review. Inhal Toxicol 2007; 19:811-32.

118. Saldiva PHN, Clarke RW, Coull BA, Stearns RC, Lawrence J, Murthy GGK, et al. Lung inflammation induced by concentrated ambient air particles is related to particle composition. Am J Respir Crit Care Med 2002; 165:1610-7. 
119. Diretoria de Mudanças Climáticas, Secretaria de Mudanças Climáticas de Qualidade Ambiental, Ministério do Meio Ambiente. 1o Inventário Nacional de Emissões Atmosféricas por veículos automotores rodoviários. Brasília: Ministério do Meio Ambiente; 2010.

120. Katsouyanni K, Touloumi G, Samoli E, Gryparis A, Le Tertre A, Monopolis Y, et al. Confounding and effect modification in the short-term effects of ambient particles on total mortality: results from 29 European cities within the APHEA2 project. Epidemiology 2001; 12:521-31.

121. Ginsberg GL, Asgharian B, Kimbell JS, Ultman JS, Jarabek AM. Modeling approaches for estimating the dosimetry of inhaled toxicants in children. J Toxicol Environ Health A 2008; 71:166-95.
122. Foos B, Marty M, Schwartz J, Bennett W, Moya J, Jarabek AM, et al. Focusing on children's inhalation dosimetry and health effects for risk assessment: an introduction. J Toxicol Environ Health A 2008; 71:149-65.

123. Asgharian B, Hofmann W, Miller FJ. Mucociliary clearance of insoluble particles from the tracheobronchial Mucociliary airways of the human lung. J Aerosol Sci 2001; 32:817-32.

124. Falk R, Philipson K, Svartengren M, Jarvis N, Bailey M, Camner P. Clearance of particles from small ciliated airways. Exp Lung Res 1997; 23:495-515.

125. Conselho Nacional de Meio Ambiente. Resolução CONAMA no. 3, de 28 de junho de 1990. Dispõe sobre padrões de qualidade do ar, previstos no PRONAR. Diário Oficial da União 1990; 22 ago.

Submitted on $11 /$ Jun/2010

Final version resubmitted on 19/Apr/2011 Approved on 26/Apr/2011 